\author{
UNIVERSIDADE DE SÃO PAULO \\ ESCOLA DE EDUCAÇÃO FÍSICA E ESPORTE
}

\title{
FORMAÇÃO CONTINUADA EM EDUCAÇÃO FÍSICA PARA PROFESSORAS DE EDUCAÇÃO INFANTIL: \\ A TÉCNICA DO DIÁRIO DE AULA
}

Valentina Piragibe

SÃO PAULO

2006

Easy PDF Creator is professional software to create PDF. If you wish to remove this line, buy it now. 


\title{
FORMAÇÃO CONTINUADA EM EDUCAÇÃO FÍSICA PARA PROFESSORAS DE EDUCAÇÃO INFANTIL: \\ A TÉCNICA DO DIÁRIO DE AULA
}

\author{
VALENTINA PIRAGIBE
}

Dissertação apresentada à Escola de Educação Física e Esporte da Universidade de São Paulo como requisito parcial para obtenção do grau de Mestre em Educação Física.

ORIENTADOR: Prof. Dr. OSVALDO LUIZ FERRAZ 


\section{Piragibe, Valentina}

Formação continuada em educação física para professoras de educação infantil: a técnica do diário de aula / Valentina Piragibe. - São Paulo : [s.n.], 2006.

xi, 156p.

Dissertação (Mestrado) - Escola de Educação Física e Esporte da Universidade de São Paulo.

Orientador: Prof. Dr. Osvaldo Luiz Ferraz.

1. Educação física infantil. 2. Formação de professores 3. Formação permanente I. Título. 


\section{AGRADECIMENTOS}

“... levanta, sacode a poeira e dá a volta por cima".

(Paulo Vanzolini,

Compositor paulista)

Ao Professor Doutor Osvaldo Luiz Ferraz por ter me orientado e demonstrado sua determinação e equilíbrio em superar as dificuldades de se realizar pesquisa em educação física escolar.

Ao meu pai, Luiz Carlos Piragibe, e em especial à minha mãe, Isabel Luiza Piragibe, por ser paciente e compreender minhas ausências. Ao Thiago, meu priminho, por ter nascido no mesmo período em que eu finalizava esta dissertação.

Ao pessoal do Grupo de Pesquisa em Educação Física Escolar, em especial à Márcia que trocou muitas idéias comigo, por também ser professora da rede pública e ter me mostrado o que significa ministrar 50 horas de aula por semana.

Ao Fábio Henrique Palladino pelo convívio durante esses três anos e ao Júlio Xavier Galharte pela boa conversa e orientação gramatical. 
Às professoras, coordenadoras, agentes escolares, vice-diretora e diretora da EMEI onde a pesquisa foi realizada. Agradeço pelos anos de convívio e acolhimento (três anos durante o mestrado e dois anos que o antecederam).

À Lúcia Franco e à Ilza Benedita, meu agradecimento e reconhecimento.

À moradia estudantil (CRUSP), que ajuda a amenizar as desigualdades de condições de muitos dos que estudam nesta universidade pública. Mas, principalmente, porque foi nela que conheci Rogério Deitali Bruno. "Assim como o ar me parece vital. Onde quer que eu vá, o que quer que eu faça, sem você, não tem graça".

Dedico este trabalho a meu avô, José Damião Piragibe. Comunista sem partido que passou a vida inteira, hoje com noventa e dois anos, acreditando em seus ideais e lutando por eles.

\begin{abstract}
Eu não me conformo que para conseguir uma bolsa de iniciação científica, um menino de dezoito anos precise antes ter um projeto. Iniciação acontece por osmose, no convívio com o pesquisador, dentro do laboratório... P or isso, eu fico muito feliz que em meus trabalhos consta nos agradecimentos: 'Este trabalho não foi financiado por nenhuma agência do governo'.
\end{abstract}

(Paulo Vanzolini, Zoólogo, Professor Emérito da Universidade de São Paulo, Jornal do Campus, maio de 2004.)

Este trabalho não foi financiado por nenhuma agência do governo. 


\section{SUMÁRIO}

Página

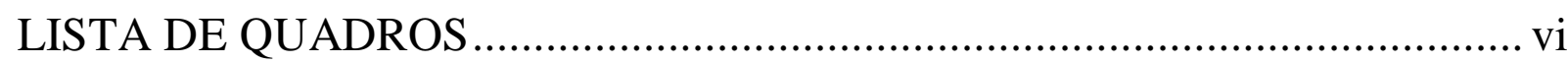

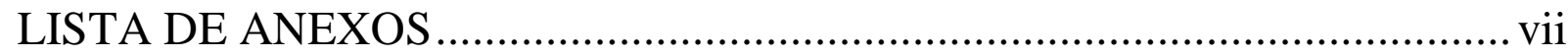

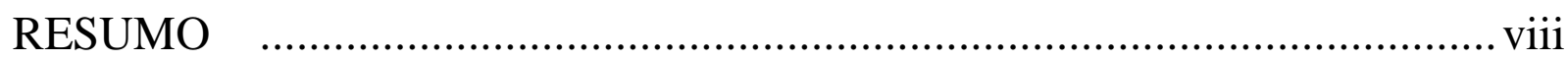

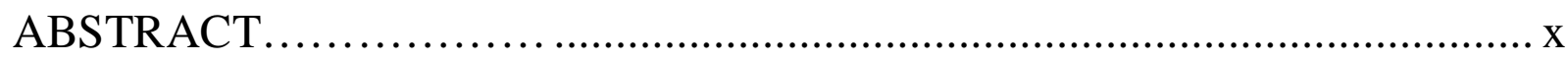

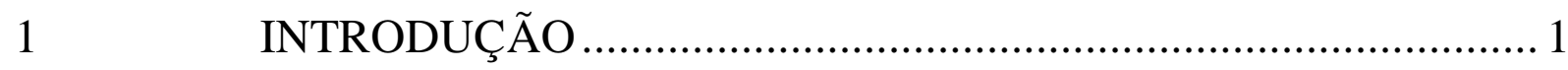

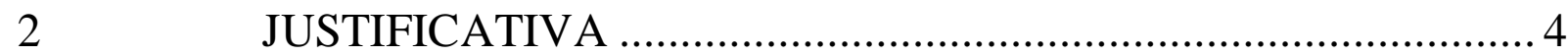

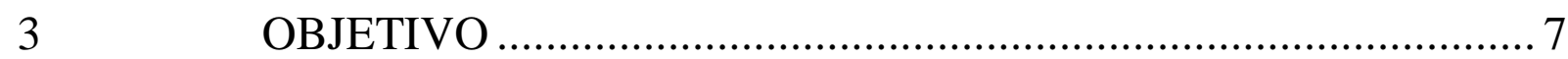

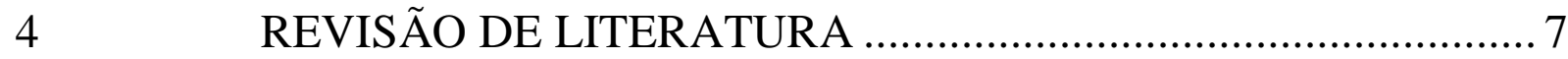

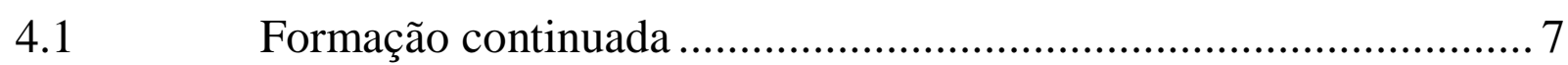

4.1.1 O professor diante da complexidade e da singularidade .................. 7

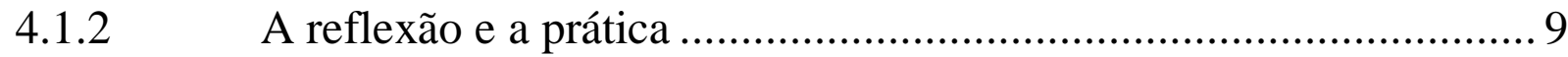

4.1.3 Aprendendo a prática reflexiva ................................................... 13

4.1.4 Desafios da proposta de educação continuada mediada pela prática reflexiva ................................................................... 14

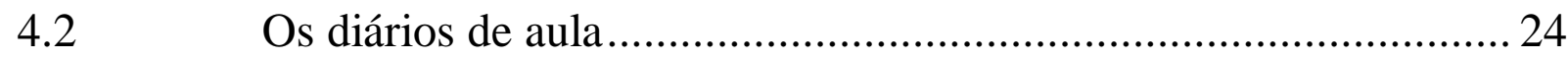

4.2.1 Os diários de aula como instrumento de investigação ................... 24

4.2.2 Os diários como forma de expressão e elaboração do

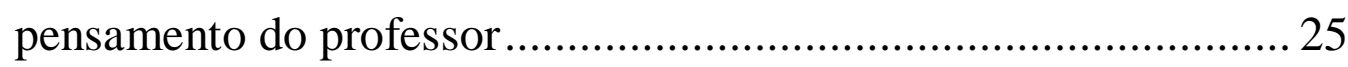

4.2.3 Cuidados metodológicos no trabalho com diários ......................... 26

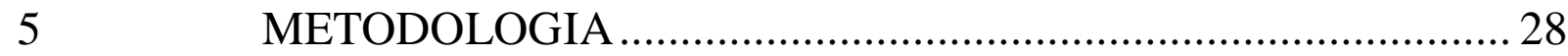

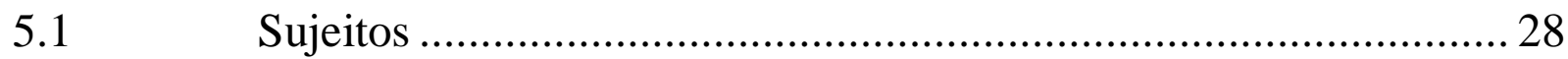


5.2 O curso de educação continuada em educação física ..................... 28

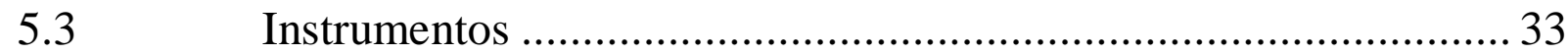

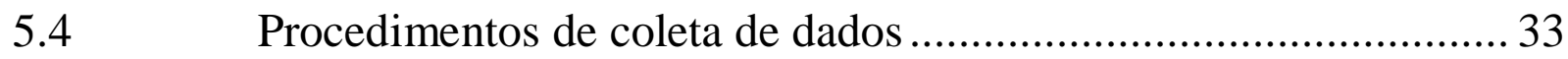

5.5 Procedimentos de análise dos dados.............................................. 35

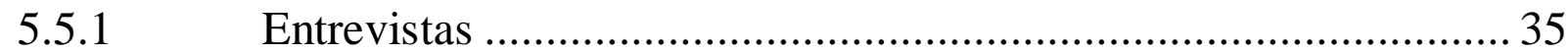

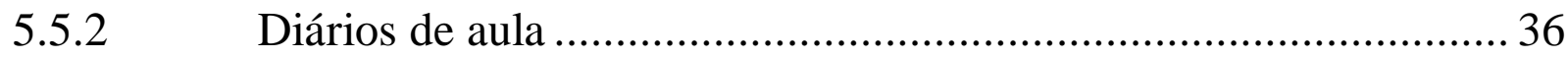

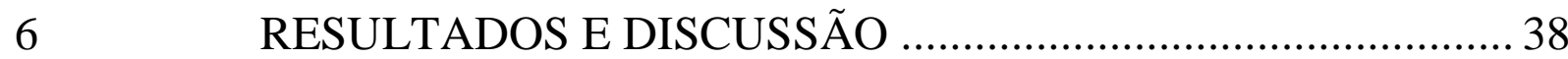

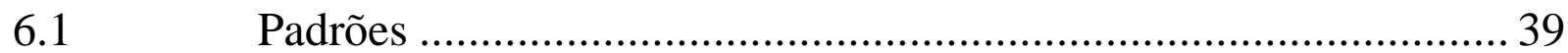

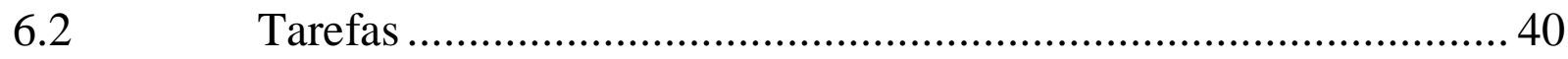

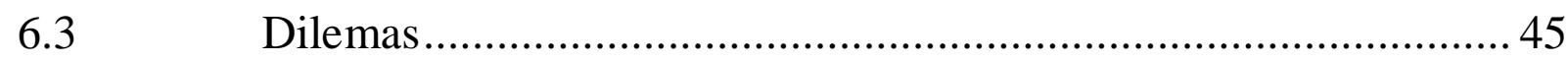

$7 \quad$ CONSIDERAÇÕES FINAIS …….......................................... 90

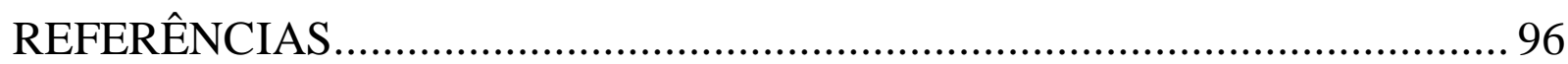

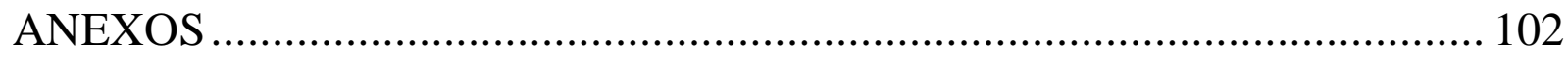




\section{LISTA DE QUADROS}

Página

QUADRO 1 - Os alunos durante a aula da professora P1 .................................. 62

QUADRO 2 - Os alunos durante a aula da professora P2 _...............................67

QUADRO 3 - Os alunos durante a aula da professora P3 ................................ 70

QUADRO 4 - Os alunos durante a aula da professora P4 …............................. 73 


\section{LISTA DE ANEXOS}

Página

ANEXO I - Modelo do termo de consentimento livre e esclarecido ............. 102

ANEXO II - Quadro de organização dos conteúdos....................................... 106

ANEXO III - Modelo de organização dos diários ........................................... 107

ANEXO IV - Roteiro da entrevista ........................................................ 108

ANEXO V - Diários da professora P2, com anotações de análise ................. 109

ANEXO VI - Quadro geral e indicadores formados com

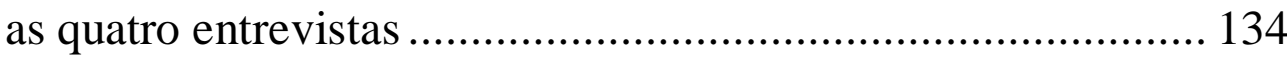




\title{
RESUM 0
}

\section{FORMAÇÃO CONTINUADA EM EDUCAÇÃO FÍSICA \\ PARA PROFESSORAS DE EDUCAÇÃO INFANTIL: \\ A TÉCNICA DO DIÁRIO DE AULA}

\author{
Autora: VALENTINA PIRAGIBE \\ Orientador: PROF. DR. OSVALDO LUIZ FERRAZ
}

Investigou-se com esta pesquisa, o processo de reflexão, sobre a prática pedagógica, de quatro professoras de uma Escola Municipal de Educação Infantil (EMEI) de São Paulo que participaram de um curso de educação continuada em educação física mediado pela técnica dos diários de aula. Realizou-se a análise de padrões, tarefas e dilemas dos diários e a análise de conteúdo das entrevistas. Nos primeiros diários, as professoras avaliavam aspectos não relacionados aos objetivos e conteúdos da aula, deixando-se envolver pelas emoções que compõem a reflexão na ação. Quando a escrita dos diários e as discussões coletivas passaram a fazer parte de sua rotina de trabalho, observaram as principais dificuldades de seus alunos em relação às habilidades fundamentais, ao trabalho com ritmo, circuitos, estafetas, tarefas. O jogo contribuiu para discussões sobre compreensão, construção e respeito a diversas regras. Houve dificuldades externas à aula que mostraram a importância do apoio pedagógico e material, tais como: a jornada completa do professor que supõe tempo suficiente para todas as atividades, sem sobrecarga de trabalho, e a valorização salarial. 
A participação das crianças nas decisões durante a aula possibilitou compreender seu modo de pensar, fez com que contribuíssem para atingir os objetivos da aula e facilitou os planejamentos e as reflexões.

Palavras-chave: formação continuada, diários, educação física infantil 


\title{
ABSTRACT
}

\section{CONTINUING PHYSICAL EDUCATION COURSE FOR PRESCHOOL TEACHERS: THE DIARY WRITING INTERPRETATIVE RESEARCH METHOD}

\author{
Author: VALENTINA PIRAGIBE \\ Adviser: PROF. DR. OSVALDO LUIZ FERRAZ
}

With this work, it is investigated the reflexion process, upon the pedagogical practice, of four teachers from a public preschool (EMEI) at São Paulo during continuing physical education course based on diaries writing interpretative research method. We analyzed diaries patterns, tasks and dilemmas and interviews content analyze. At the first diaries the teachers didn't consider the objectives and content during class evaluation, keeping involved by "tangled emotions" that make up the reflexion in action. When the writing diaries and the collective discussions became part of their working routine, they could notice the main students' difficulties related to fundamental skills and to the work with rhythm, circuits, file squads and learning centers (stations). The play contributed in discussions about understanding, building and respect many rules. There were difficulties outside the class that showed the material and pedagogical support importance, as to increase the salaries and to guarantee the full-time journey to the teachers. It supposes enough time for all activities without overburden work. 
With the children involvement in decisions, during the class, it became possible to understand their thinking way, to make them help with the class goal and to make planning and reflexion easier.

Key Words: preschool physical education, continuing education, diaries. 


\section{INTRODUÇÃO}

Em décadas passadas, a maioria dos programas públicos de atendimento a crianças de zero a seis anos de idade era baseada no assistencialismo. Tais programas surgiram da luta das mães que trabalhavam fora de casa e precisavam de um local para deixar seus filhos, com o propósito de que estes recebessem os cuidados mínimos de higiene e alimentação.

Atualmente, o Governo Federal propõe o atendimento às crianças de zero a seis anos buscando o desenvolvimento de todas as suas potencialidades. Pelo menos em teoria, como foi demonstrado pelo Referencial Curricular Nacional para a Educação Infantil (BRASIL, 1998).

Mas como colocar em prática as propostas desse referencial, sabendo-se que nem todas as áreas do conhecimento vêm sendo trabalhadas pelos professores, incluindo-se aí a educação física?

Existem várias possibilidades de cursos que poderiam auxiliar na resposta a esta questão, mas muitos deles são baseados na transmissão de conhecimento, como os cursos de reciclagem e treinamento. Enquanto o primeiro considera o professor um material passível de ser desmanchado e refeito, o segundo tem como foco a modelagem de comportamentos, que dependem de automatismos e não da manifestação da reflexão com autonomia.

Já a proposta da formação continuada traz a concepção de educação como um processo prolongado para a vida toda, em contínuo desenvolvimento e que valoriza os conhecimentos que o professor já possui. Tais saberes, de acordo com TARDIF (2000), provêm de diversas fontes, como, por exemplo, da vida escolar anterior e da vida pessoal, e são adquiridos com o passar do tempo. Também são oriundos de conhecimentos didáticos e pedagógicos originários de sua formação profissional, de saberes curriculares veiculados pelos programas, 
guias e manuais escolares, do saber ligado à experiência de seu próprio trabalho e do trabalho de certos professores.

Todos esses saberes precisam ser observados de perto nas propostas de educação continuada de professores porque, embora os profissionais do ensino sejam em parte determinados pela estrutura social e cultural dominante, são ao mesmo tempo atores que possuem conhecimentos.

Dentre as estratégias em formação continuada, como palestras e oficinas, os diários de aula têm demonstrado sua contribuição por estimularem o processo de reflexão dos professores. (ZABALZA, 1994; ZIBETTI, 1999).

Diante deste quadro, esta pesquisa buscou investigar o processo de reflexão, sobre a prática pedagógica, de um grupo de professoras de uma Escola Municipal de Educação Infantil (EMEI) de São Paulo, durante o processo de educação continuada em educação física mediado pela técnica dos diários de aula.

Foi levado em consideração, também, que essas professoras não lecionavam educação física antes do curso. Isto porque nas EMEIs da prefeitura de São Paulo é o professor generalista que deve lecionar todas as áreas do conhecimento. Mas em algumas cidades já há a presença do especialista licenciado em educação física para trabalhar movimento com essa faixa etária, como por exemplo, em Florianópolis (GRUPO DE ESTUDOS AMPLIADOS DE EDUCAÇÃO FÍSICA, 1996).

Trata-se de uma pesquisa com ênfase qualitativa e ANDRÉ (2000) explica as características deste tipo de pesquisa como sendo aquela que busca a interpretação em lugar da mensuração, a descoberta em lugar da constatação. Além disso, esta abordagem de pesquisa valoriza a indução e assume que fatos e valores estão intimamente relacionados, não havendo uma postura neutra do pesquisador. 
Dentre os diferentes tipos de pesquisa qualitativa, como a do tipo etnográfica, a participante, a pesquisa-ação, etc., utilizamos aqui o estudo de caso. O estudo de caso é um estudo descritivo de uma unidade que tem limites bem definidos e, de acordo com STAKE (1995), procura-se encontrar bons momentos que revelem a complexidade única do caso.

$\mathrm{Na}$ revisão bibliográfica, foram tratados dois temas: formação continuada e diários de aula. O primeiro discutiu a complexidade da ação docente e o fato de que os professores nem sempre sabem em qual circunstância aplicar os conhecimentos que possuem. Além disso, apontou a prática reflexiva como uma possibilidade de articulação dos saberes desses professores. O segundo tema mostrou os diários de aula como veículo facilitador dessa prática reflexiva.

Em seguida, na metodologia, foram caracterizados os sujeitos da pesquisa e o curso de educação continuada do qual participaram. Também foram detalhados os procedimentos para coleta de dados, que compreenderam entrevista semi-estruturada e obtenção de um ano de diários, e análise dos dados, baseada em TRIVIÑOS (1987) e ZABALZA (1994).

Nos resultados e discussão, foram mostrados os pontos convergentes e peculiares que apareceram tanto na entrevista quanto nos diários de cada professora. Estes pontos trataram principalmente dos dilemas enfrentados por estas educadoras antes, durante e depois de suas práticas pedagógicas em educação física. A partir daí, pôde-se investigar o processo de reflexão dessas professoras em sua formação e se este contribuiu para alterar sua prática pedagógica. 
É de reconhecimento geral que o movimento desempenha um aspecto importante no desenvolvimento da criança. Corroborando essa perspectiva, o Referencial Curricular Nacional para a Educação Infantil (BRASIL, 1998) coloca a educação física como um elemento importante da prática pedagógica desse ciclo de escolarização.

Embora este documento traga uma proposta de educação física na educação infantil, as escolas municipais não a estão colocando em prática, conforme verificado por FERRAZ (2000). Apesar de 90\% dos 196 professores participantes da pesquisa ${ }^{1}$ possuírem formação universitária, $46 \%$ desses profissionais não trabalhavam a área de educação física. Os educadores justificavam a ausência desse trabalho devido à formação inadequada que receberam.

Dentre os professores que afirmaram trabalhar a educação física, $56 \%$ consideravam esta área importante por possibilitar o desenvolvimento global da criança. As respostas dos outros $48 \%^{2}$ indicaram fatores tais como: desenvolvimento físico (21\%), socialização (4\%) e saúde (1\%).

É interessante observar que $22 \%$ dos que afirmaram dar aulas de educação física não conseguiam responder sobre a importância da disciplina.

Já a resposta dos $56 \%$ que falaram em desenvolvimento global pode ser considerada positiva por apontar o princípio da totalidade no desenvolvimento infantil. Mas também pode demonstrar uma dificuldade dos professores em diferenciar a educação física das demais áreas e delimitar sua especificidade. Desta forma, o conceito de desenvolvimento global estaria

\footnotetext{
${ }^{1}$ Professores lotados, na época da pesquisa, na $12^{\mathrm{a}}$. Delegacia Regional de Ensino da Rede Municipal de Educação Infantil de São Paulo.

${ }^{2}$ Nesta questão da pesquisa, os professores podiam optar, concomitantemente, por mais de uma categoria de importância, permitindo que a soma das frequêencias ultrapassasse $100 \%$.
} 
destituído de sentido mais profundo, aproximando-se mais das representações sobre a área da educação física que são veiculadas quase como "senso comum".

Nessa mesma pesquisa, 85\% do total de professores investigados desejavam ter acompanhamento pedagógico para educação física, o que indica a necessidade de cursos formativos.

Portanto, é necessário o investimento na formação de professores. Não como um simples treinamento para a competência individual em certas atividades de aula, mas como o desenvolvimento de uma classe de intelectuais que se guiam por valores democráticos e cultivam a capacidade crítica de seus alunos.

Infelizmente, muitos desses cursos ainda se preocupam com esse treinamento e, como alerta CRUZ (1996), em geral, a transmissão de conhecimentos é a tônica desses cursos. Neles, o professor é tratado da mesma forma a qual se espera que não tratem seus alunos: como se não soubessem nada ou quase nada, não criassem, não fizessem relações e não atribuíssem significados. Portanto, não se pode esperar que esses professores tenham uma relação diferente com seus alunos.

Por outro lado, um curso de educação continuada pode proporcionar um levantamento das necessidades dos professores, problematizando essas necessidades mediante uma postura crítica sobre soluções inadequadas. De acordo com MARIN (1995), esta prática auxilia os profissionais a participarem ativamente do mundo que os cerca, incorporando tal vivência no conjunto dos saberes de sua profissão.

Para que a formação continuada não trate de temas abstratos e desvinculados da realidade dos professores, mas que realmente aborde suas necessidades, é preciso estar integrada e participando do dia-a-dia da escola, analisando suas peculiaridades históricas. 
Essa vinculação com a escola, onde trabalhar e formar não são atividades distintas, enriquece-se quando unida à universidade, incluindo assim referenciais teóricos científicos da psicologia e da sociologia, por exemplo. Desta forma, o trabalho é realizado em ligação estreita com o desenvolvimento curricular e a organização da escola, favorecendo a participação dos diversos atores da vida da instituição e a emergência de práticas democráticas. (CARVALHO, ABUD, ALMEIDA, ALMEIDA, BASSETO, BOLZANI FILHO, CAMARGO, CAMPAÑA FILHO, DIAS, DICK, DRUCK, FALJONIALÁRIO, FERNANDES, FERRAZ, GARCIA, GARRIDO, GIANINI, GOMES, KAWAMURA, KUNDMAN, LOPES, MACHADO, MARCONDES, MENDONÇA, MINTO, OLIVEIRA, PATTO, PEREIRA, PERES, PIPITONE, PONTUSCHKA, PORTO, RESENDE, RIBEIRO, RIVAS, SALLES, SANO, SCARLATO, TOLEDO, VIANNA \& ZUFFI, 2004; NÒVOA, 1992, 2004; SCHÖN, 1987a; TARDIF, 2000).

Conseqüientemente, programas de educação continuada centrados na escola assumem um papel relevante para os profissionais de educação infantil.

$\mathrm{Na}$ diversidade de programas em formação continuada, uma das possibilidades é a utilização do diário de aula como técnica para formação. (ZABALZA, 1994; ZIBETTI, 1999). Os diários têm a vantagem de produzir um feedback autoproporcionado, ou seja, ao escrevê-lo, tem-se imediatamente o resultado da ação pedagógica que gera um processo cíclico de criação-revisão da informação sobre quem escreve e sobre o que se está escrevendo. Há uma reconstrução do discurso prático e da atividade profissional, freqüentemente acompanhada de justificativas sobre os porquês que fundamentam os fatos narrados.

A análise da literatura nacional demonstra a pouca incidência de pesquisas em formação continuada na área de educação física de uma maneira 
geral e, especificamente, que utilizam a técnica do diário de aula, o que indica desta forma a importância do presente estudo.

\section{OBJETIVO}

Investigar o processo de reflexão, sobre a prática pedagógica, de professoras generalistas de educação infantil de uma Escola Municipal de Educação Infantil de São Paulo, que não lecionavam educação física e participaram de um programa de educação continuada nesta área do conhecimento, mediado pela técnica dos diários de aula.

4

\section{REVISÃO DE LITERATURA}

\subsection{Formação continuada}

\subsubsection{0 professor diante da complexidade e da singularidade}

O ensino é uma "arte" e sua complexidade repousa no fato de que o professor atua em relações humanas com seus alunos e demais professores, mediante conteúdos, espaços, materiais e interesses diversificados. De acordo com PERRENOUD (2001), dessas relações humanas surgem constantes antagonismos difíceis de serem simplificados. A desordem e a incerteza perturbam a aula e o professor perde as distinções e as clarezas.

Assim sendo, num curso de educação continuada não se deve esperar a solução de todos os problemas, já que novos dilemas sempre surgirão. Mas pode-se contribuir tornando-os mais claros para que sejam trabalhados, possibilitando mudanças na maneira de pensar. Segundo PERRENOUD (2001), trabalhar com a complexidade é lidar com nossos preconceitos, nossas representações enraizadas em uma experiência, em uma cultura, em uma rede de relações. 
Esses dilemas ou certezas, específicos de cada professor e que precisam ser trazidos à tona, vêm carregados de conteúdos afetivos como desejos e inseguranças que dificultam a administração das relações interpessoais. Segundo SCHÖN (1987a), cada professor se atém a diferentes fatos e a estes estabelece diferentes significados.

Um programa de educação continuada também não deve se restringir a fornecer conhecimentos técnicos aos professores. Isto porque, com freqüência, as situações-problema se apresentam como casos únicos que não pertencem a nenhuma categoria de teorias, e as quais o professor não pode tratar como problemas instrumentais a serem resolvidos simplesmente aplicando-se regras.

De acordo com SCHÖN (1987a), é preciso certa improvisação, criatividade e teste de estratégias elaboradas pelo próprio professor, o que é chamado de talento artístico. Talento esse que o professor possui ao ensinar lidando com zonas indeterminadas da prática, tais como a incerteza, a singularidade e o conflito. Com esse talento, o professor nomeia e estabelece relações que tornam o problema bem definido e possibilitam a aplicação dos conhecimentos técnicos na resolução de problemas. Este é um caminho de construção pessoal, e por isso, mais lento e trabalhoso.

Ademais, algumas situações envolvem conflitos de valores, havendo a necessidade não apenas de se chegar a um resultado consistente, mas de reconciliar ou de fazer escolhas entre apreciações conflitantes a fim de se formular um problema de forma coerente e que valha a pena ser resolvido.

Fica fácil, então, compreender o resultado do estudo de ALARCÃO (1996) sobre formação de professores realizada em Portugal. Esta pesquisadora observou que embora os educadores sejam detentores dos saberes declarativo e processual, falta-lhes conhecimento contextual e estratégico. Provavelmente, 
podem-se encontrar os mesmos resultados em pesquisas no Brasil, haja vista a complexidade da ação docente.

Uma forma de construção desse saber contextual e estratégico que falta aos professores é mediada pela prática reflexiva, articulando os conhecimentos que o professor possui.

\subsubsection{A reflexão e a prática}

Segundo PERRENOUD (1999), qualquer pessoa colocada em uma situação difícil, sem formação, desenvolve uma atitude reflexiva por necessidade. Professores nesta condição acabam aprendendo os conhecimentos elementares, mas com sofrimento, quando poderiam tê-los construído durante sua formação profissional, de maneira mais positiva.

Por isso a importância do estímulo à reflexão já na formação inicial, devendo estender-se por toda a formação continuada e desta maneira contribuindo para que os professores não enfrentem situações difíceis sentindose isolados em sua prática, aprendendo somente por tentativa e erro.

A prática reflexiva pode ocorrer tanto para solucionar problemas como para tornar o trabalho mais eficaz.

Em um primeiro momento, pode parecer mais interessante ao professor praticar a reflexão com o objetivo de solucionar os problemas que enfrenta no dia-a-dia. O que não é má idéia diante dos inúmeros dilemas enfrentados na complexidade característica do ensino, exigindo que o professor aja na urgência e decida na incerteza. Mas a reflexão não deve ocorrer somente quando há problemas. É preciso pensar além destes, é preciso ter como objetivo um trabalho mais eficaz, o que pode até diminuir o número de problemas futuros ou atenuá-los. 
Para PERRENOUD (1999) essa prática reflexiva deve ser imaginada como um funcionamento estável, uma prática metódica para o domínio da complexidade, inscrita no tempo de trabalho como uma rotina e ao mesmo tempo como um estado de alerta permanente. Por isso, ela tem necessidade de disciplina e de métodos para observar, memorizar, escrever e analisar após compreender e escolher novas opções.

Isso significa, que havendo ou não problemas, deve existir a prática reflexiva como parte integrante da rotina de trabalho. E que esta rotina não seja vista como monotonia, passando por cima de muitos detalhes que poderiam instigar novos pensamentos e novas formas de agir.

É preciso, por outro lado, considerar que não é possível a um professor lecionar quarenta horas de aula por semana e se manter em estado de alerta. A menos que esteja com estresse crônico.

Ressalta-se, também, a disciplina exigida pela prática reflexiva e a importância de períodos diários de estudo dentro da carga horária do professor. Este, somente de tal forma, poderá redigir e organizar seus pensamentos sobre a aula, ter o momento rico de troca com os demais professores, aprofundar seus conhecimentos teóricos e escolher novas opções.

De acordo com o que se discutiu anteriormente, a prática reflexiva pode ocorrer tanto para solucionar problemas como para tornar o trabalho mais eficaz. Em qualquer um dos casos, pode-se refletir antes, durante e após a ação. Além disso, pode-se refletir sobre a reflexão na ação.

A reflexão anterior à ação é importante não somente para planejar aulas, mas também para preparar o professor para acolher os imprevistos e guardar maior lucidez, sobretudo num ofício onde os problemas são recorrentes.

$\mathrm{Na}$ reflexão durante a ação, o profissional cria uma seqüência de procedimentos onde se testam alternativas de compreensão do fenômeno para 
resolver um problema. É um processo que pode ser realizado sem que se saiba falar sobre ele. E, segundo PERRENOUD (2001), este é próprio de toda ação complexa, a qual, para ser comandada em tempo real, exige a constante análise da situação evolutiva e das possibilidades que surgem a cada instante.

Nesta reflexão, a pessoa encontra-se envolvida na situação problemática que pretende modificar, sendo afetivamente sensível a todos os obstáculos e resistências do momento (PÉREZ GÓMES, 1992). Por isso, é uma reflexão que não tem o rigor e o distanciamento requeridos para uma análise racional, mas permite a improvisação e a criação, e o também chamado talento artístico.

LALANDA e ABRANTES (1996) estudaram o conceito de reflexão que John Dewey explicou, já em 1910 e 1933. Estas autoras apresentam um conceito de reflexão que é muito semelhante ao conceito de reflexão na ação de SCHÖN (1987a).

Assim que se deparam com um problema, as pessoas desejam ver a situação resolvida o mais depressa possível, mas essa ação imediata é adiada pelo aparecimento de várias sugestões que vêm à mente e inibem ações precipitadas. As sugestões confundem-se e faz-se necessário clarear o problema, defini-lo e fazer um registro mental dele. Com dados mais realísticos estabelecese uma hipótese que é confrontada com o real para poder ser aceita ou rejeitada. (LALANDA \& ABRANTES , 1996).

Nem sempre é possível clarear o problema, devido à pressa para se cumprirem todas as atividades de aula programadas ou porque a prática tornouse uma rotina repetitiva, não permitindo ao professor sequer ter consciência da existência de problemas. Seu conhecimento prático vai se fossilizando, aplicando indiferentemente os mesmos esquemas a situações cada vez menos semelhantes. 
Além disso, a confusão mental costuma persistir em professores iniciantes que não conseguem estabelecer uma atenção seletiva para as múltiplas variáveis intervenientes. Estes professores não sabem identificar quais os aspectos são relevantes e que merecem ser levados em consideração.

Logo, a prática reflexiva se mostra importante para tornar consciente muitos aspectos presentes nas aulas e, ao mesmo tempo, contribuir para que os professores iniciantes comecem a fazer uso de filtros seletivos de informações, dirigindo sua atenção aos aspectos mais relevantes da aula.

SCHÖN (1987b, 1992) afirma que quando o professor direciona sua atenção para ouvir o que a criança tem a dizer, então o ensino se transforma em uma forma de reflexão na ação. Nesse processo, os professores levantam hipóteses sobre a variedade de soluções que as crianças podem dar a um problema (giving kids reason) e são efetuadas experiências para testar essas hipóteses sobre o modo de pensar do aluno. Mediante a reflexão na ação, o professor pode entender a compreensão figurativa ${ }^{3}$ que o aluno traz para a escola.

A reflexão após a ação permite uma análise distante e serena por ser posterior aos acontecimentos. São questionados os procedimentos utilizados nas fases de diagnóstico e definição do problema e da escolha de meios para solucioná-lo (SCHÖN, 1987a).

Ao refletir sobre a reflexão na ação são evidenciadas as teorias implícitas, os sentimentos provocados pela situação, as convicções e as formas de representar a realidade, que freqüentemente não são expressos e precisam tornar-se conscientes (GARCIA, 1992; PÉREZ GÓMEZ, 1992; ZEICHNER, 1993).

\footnotetext{
${ }^{3}$ As representações figurativas implicam agrupamentos situacionais que se estabelecem na maior proximidade possível das experiências cotidianas. Já as representações formais implicam referências fixas, tais como o saber escolar.
} 
É uma análise que deve ser feita coletivamente, pois, de acordo com NÒVOA (2004), PERRENOUD (1999) e ZEICHNER (1993), permite que as opiniões singulares sejam submetidas à opinião dos outros, aumentando as chances dos professores perceberem suas falhas e aprenderem uns com os outros.

O grupo não deve ser visto como agente punitivo do pensamento do professor, mas como um suporte numa prática social, sustentando o crescimento de todos, fazendo perceber que a situação de um está ligada à do outro.

A partir dessa análise, é que se pode diversificar o repertório pedagógico como resultado de diferentes pontos de vista e das leituras, investigações e questionamentos estimulados.

\subsubsection{A prendendo a prática reflexiva}

Pelo que se discutiu até agora, a prática reflexiva auxilia o professor a planejar sua ação; antecipar a implementação do plano acolhendo imprevistos; direcionar sua atenção; durante a aula, a tornar consciente o diagnóstico, a definição do problema e a escolha de meios para solucioná-lo; e nas discussões coletivas, a questionar seus conhecimentos tácitos.

GARCIA (1992) acrescenta que a prática reflexiva também possibilita ao professor analisar dados coletados a partir da prática e construir uma teoria; avaliar e emitir juízos sobre a importância dos resultados; relacionar a análise com a prática e comunicar suas idéias aos colegas.

É importante lembrar que todas essas atividades demandam tempo, que nem sempre o professor possui dentro de sua jornada de trabalho. Mas considerando-se que haja esse período diário de pesquisa e estudo, trata-se de um processo que se aprende ao ser posto em prática, onde o aprendiz precisa correr o risco de perder seu senso de competência e controle, abandonando temporariamente algumas crenças. 
Ao serem suspensas algumas crenças, também é suspensa a autonomia e é o formador que ajudará a aquisição da compreensão, direção e competência, entrando numa relação temporária de verdade e dependência na qual um contrato de aprendizagem entre ambos precisa ser explicitado, deixando clara a expectativa de se estabelecer um diálogo constante. Quando o professor age de acordo com o que viu ou ouviu é que de fato revela a ele mesmo e ao formador os conhecimentos anteriores que traz consigo e a compreensão, ou sua falta, construída em relação à intervenção do orientador (SCHÖN, 1987a).

O parágrafo acima mostra o formador como um suporte importante ao professor em sua prática reflexiva e para a discussão coletiva do trabalho. O professor, por sua vez, precisa se esforçar para construir novos significados diante dos questionamentos colocados pelas discussões coletivas.

\subsubsection{Desafios da proposta de educação continuada mediada pela prática reflexiva}

\section{A prática reflexiva e sua relação com o conhecimento científico}

Há uma apreensão que recai sobre a prática reflexiva quando esta se preocupa somente com a prática, com o saber fazer, deixando os conhecimentos científicos fora das discussões dos professores.

DUARTE (2003) e ARCE (2001) destacam o poder do conhecimento científico para explicar e transformar o real e que a superação das limitações próprias do pensamento cotidiano são possíveis apenas com o desenvolvimento do pensamento conceitual e as articulações com operações teóricas que se aprende na escola.

Segundo esses autores, a prática reflexiva abandona os conhecimentos teórico, acadêmico e científico, além da exclusão da aprendizagem de conteúdos. 
Por outro lado, LELIS (2001) afirma que ao problematizar uma perspectiva centrada no saber acadêmico, estimula-se o redimensionamento do sentido da teoria, tomando-a mais como uma hipótese, sendo a verdade considerada como processo, provisória e parcial.

A metodologia do prático reflexivo não exclui o ensino tradicional que comunica informações. Segundo ALARCÃO (1996), embora a aprendizagem do fazer mediante o fazer e o desenvolvimento da sensibilidade criativa sejam dois elementos fundamentais na educação profissional, esta não exclui a aprendizagem de regras, fatos e conceitos.

Desta maneira, a teoria está presente na prática reflexiva, mas para ser compreendida mediante a sua aproximação com a experiência acumulada dos alunos e do professor. Experiência esta específica de cada pessoa e que, portanto, contribui para a atribuição de diferentes significados sobre um mesmo conhecimento científico.

\section{Os pressupostos associados ao local da formação}

Alguns autores afirmam que está havendo uma degradação do envolvimento da universidade na formação de professores devido à prática reflexiva, deslocando esse processo para as escolas, sem que haja vinculação com a universidade.

Segundo FREITAS (2002), DUARTE (2003) e ARCE (2001), corre-se o risco de limitar a visão da educação e a capacidade crítica, e nega-se ao professor a sua identidade como cientista e pesquisador da educação.

Por outro lado, LÜDKE (2001), em sua pesquisa com professores do ensino médio da rede pública do Rio de Janeiro, constatou que dentre os professores que realizavam pesquisas em seus locais de trabalho, a maioria apontou os cursos de mestrado e doutorado como caminho para se aprender a 
pesquisar. Poucos apontaram os cursos de graduação como responsáveis por essa formação.

Realmente é importante que a universidade faça parte da vida do professor, mas a pesquisa acima demonstra a necessidade de mudanças nos cursos de graduação, se estes quiserem formar profissionais que também pesquisem.

Para o professor, seria interessante que isso acontecesse, pois poderia, ao menos, ser um consumidor crítico das pesquisas em educação, possibilitando o enriquecimento de seu trabalho junto aos alunos, compreender os pressupostos e compromissos morais de vários programas e tomar decisões com autonomia.

Por outro lado, a escola também é primordial para essa formação. É nela que acontecem as múltiplas situações singulares e inesperadas que o professor precisa resolver ou ao menos administrar.

Quando a escola que integra essa formação universitária é pública, podem ser estimuladas reflexões acerca dos valores democráticos e da educação como direito de todos, além do contato com a natureza complexa da arte de ensinar.

Para CARVALHO et al. (2004) e ZEICHNER (1993), os professores precisam manter um impulso democrático e emancipador, aprendendo a lidar com a diversidade da população atendida nas escolas públicas, respeitando ativamente as diversas tradições culturais, e contribuindo para a transformação da realidade.

Nem sempre a integração universidade-escola acontece de fato e, quando ela acontece, pode vir acompanhada de alguns problemas. Isso porque tanto o professor quanto o pesquisador precisam estar confiantes e predispostos para verem suas certezas como algo relativo. De tal forma que os professores não 
considerem seus conhecimentos como íntimos e impossíveis de serem teorizados; e que os pesquisadores respeitem os saberes dos professores.

Segundo TARDIF (2000), este posicionamento exige o questionamento dos fundamentos das identidades profissionais de ambos os colaboradores, bem como a capacidade de navegarem à vontade em culturas profissionais distintas da sua.

Além desses fatores, é preciso estar atento à forma como o curso é realizado, se há metodologia para observar, escrever e analisar após compreender e escolher novas opções mediante a prática reflexiva. Além disso, há que notar se a carga horária é condizente com a construção do conhecimento por parte do professor. Construção esta que é um processo pessoal, demandando mais tempo do que um curso de treinamento, por exemplo. De acordo com PERRENOUD (1999), para que a atitude reflexiva se torne um componente do habitus ${ }^{4}$ profissional dos professores, não basta confiar na essência da instituição, é preciso instaurar dispositivos precisos para a formação.

\section{Amplitude da reflexão}

O primeiro aspecto a se observar sobre a amplitude da reflexão é que alguns cursos de educação continuada se dizem reflexivos, mas, na realidade, fazem com que o professor imite melhor a prática sugerida por investigações que outros produziram, negligenciando as teorias e saberes desse professor e limitando seu potencial de reflexão e de liderança.

Além dos cursos que não estimulam a reflexão, entre outros, quando ela é estimulada, pode estar restrita às estratégias de ensino, ao professor individualmente ou em sua relação com os alunos, excluindo os componentes

\footnotetext{
4 PERRENOUD (2001) define habitus como um conjunto de esquemas que um sujeito dispõe em um determinado momento de sua vida.
} 
sociais ligados à escola e à secretaria de educação. Esta reflexão também pode considerar a cultura do professor como modelo, dificultando a aproximação com a população atendida, ou ainda não questionar se o formador aplica a prática reflexiva para si.

De acordo com ZEICHNER (1993), quando o professor pensa sozinho sobre seu trabalho, acaba por ver os problemas como sendo apenas seus, sem relação com os dos outros professores, com a estrutura da escola e com o sistema educativo. Com essa tendência individualista, é pouco provável que confronte e transforme os aspectos estruturais que dificultam seu trabalho.

Este individualismo pode se dar tanto na estrutura do curso, quanto na opção de trabalho por parte do professor que tem resistência em praticar a reflexão coletiva. Essa atitude esconde o medo de ter que se esforçar mais no trabalho, de enfrentar os outros e mesmo de ser obrigado a mudar de prática.

De acordo com PERRENOUD (2001), isso acontece porque a relação pedagógica e a gestão da sala de aula envolvem o professor naquilo que ele tem de mais íntimo, no que concerne à sua identidade, à sua maneira de ser no mundo, aos seus valores e atitudes menos negociáveis ou justificáveis, as suas certezas.

A resistência pode representar igualmente uma fuga dos padrões e expectativas que o grupo impõe ao professor. GOFFMAN (2001) explica que a imersão obrigatória na atividade da organização envolve padrões (de bem-estar, de valores, de incentivos e de sanções). Esses padrões delineiam uma concepção de ser humano ao dizer o que deve ser feito e por que deve ser feito, presumivelmente diz tudo o que a pessoa pode ser e espera-se que ela concorde. Tais suposições a respeito do "eu" são enfrentadas pelo indivíduo, que pode assumir diferentes posições entre a identificação com a organização e a oposição 
a ela. Diante da menor pressão está pronto a reconquistar seu equilíbrio, desviando sua participação para qualquer um dos lados.

O enquadramento aos moldes da instituição escolar, ou até mesmo às políticas impostas para a formação, pode levar o professor a atitudes defensivas. Da mesma forma, a rigidez escolar pode gerar resistência por parte dos alunos.

FOUCAULT (1987) também fala de enquadramento e forte disciplina em instituições como o quartel, o convento, o hospital e a escola, onde o corpo é modelado e treinado, devendo obedecer e ser útil. O objetivo desse controle é acabar com sua linguagem, com sua comunicação, formando corpos dóceis e passíveis de dominação.

KISHIMOTO (2002) cita o exemplo na educação infantil em que ocorre o aprendizado mecânico de letras e números. As crianças são encerradas no interior de quatro paredes, privilegiando estruturas semelhantes às prisões, com vigilância total e rotinas rígidas para disciplinar pequenos "rebeldes".

Às vezes, os momentos de "indisciplina” são a mais natural reação de jovens não "engessados". Diante de um ambiente disciplinador, fica difícil levar os estudantes a valorizarem e a praticarem a democracia em suas vidas cotidianas, quando as atividades rotineiras na escola estão regidas por relações de mando e submissão.

Pela prática reflexiva, o professor é levado a questionar essas relações. Cabe ao formador, por sua vez, estar atento à estruturação do curso, à sua atuação e expectativas para não conduzir uma formação disciplinadora como é a relação criticada acima.

Além da reflexão sobre ambientes disciplinadores, é preciso estar atento para não tomar a cultura do professor como modelo. De acordo com ZEICHNER (1993), muitos programas formativos têm orientação curricular 
ocidental, branca, masculina e de classe média, havendo um grande fosso entre a cultura dessas escolas e a cultura da comunidade.

Quem não se enquadra nesse estereótipo é colocado à margem, não havendo tentativas de aproximação e entendimento dos conhecimentos e da cultura que os alunos trazem. A reflexão gira em torno da perplexidade do professor diante de "famílias desestruturadas", que dificultam a aprendizagem do aluno, e de alunos rebeldes que se recusam a participar e têm "comportamentos não condizentes com a escola”.

\section{As políticas públicas para a formação e a prática reflexiva}

Em muitos casos, o que vemos é a iniciativa privada oferecendo cursos de educação continuada e materiais didáticos com a grife de empresas educacionais "atestando a seriedade e a eficiência" de seu método de ensino. Acabam transmitindo também os pressupostos para a educação, que podem ser outros que não a preocupação com valores públicos. Proliferam, por exemplo, cursos de especialização na área escolar oferecidos por faculdades particulares. Esses cursos suprem uma demanda de professores que desejam continuar estudando em busca de maior qualidade em seu trabalho, desde que consigam pagar por isso.

Esta transferência de responsabilidade na área da educação, passando do Estado para a iniciativa privada, é um fenômeno que ocorre tanto em países desenvolvidos, como nos países em desenvolvimento.

$\mathrm{Na}$ França, por exemplo, PERRENOUD (1999) mostra que o objetivo do governo é conservar o adquirido gastando menos, uma vez que o Estado não tem mais os meios de desenvolver a educação como nos tempos de crescimento. 
No Brasil, a causa da falta de investimentos é um pouco diferente. Com a expansão do ensino público surge a necessidade de se formar uma quantidade maior de professores para atender à crescente demanda. Mas construir ou ampliar universidades públicas com boa infra-estrutura, pesquisa, bons profissionais e salários dignos aumentaria os gastos do governo. Este aumento de gastos estaria na contra-mão da política de contensão, característica do Estado mínimo brasileiro. De acordo com FREITAS (2002), o Estado brasileiro resolve criar um sistema misto (tanto público quanto privado), de caráter técnico-profissionalizante e com custo baixo, os Institutos de Ensino Superior (IES). Estes cursos não são obrigados a investir em pesquisas, proporcionam uma formação aligeirada em seu conteúdo e em seu tempo de duração, comprometendo a qualidade da educação.

Além da progressiva retirada de recursos públicos, a reforma educacional baseia-se em mecanismos de controle sobre o trabalho docente por meio de avaliações realizadas pelo Ministério da Educação. FREITAS (2002) comenta que quando a avaliação dos estudantes, ao final de cada ano letivo, passa a ser realizada não pelos professores e pela instituição escolar, mas por uma prova nacional, é tempo de se perguntar que tipo de profissional de educação a política publica pretende construir.

Desta maneira, muitos professores, saídos dos IES, possuem formação deficiente e uma prática pedagógica controlada pelas avaliações do governo, comprometendo a autonomia docente.

Uma opção interessante, para a formação, surge com os sindicatos que representam os professores e começam a oferecer cursos que, no entanto, mostram-se fracionados e sem articulação com um projeto mais amplo. Portanto, essa alternativa não pode eximir o poder público de sua responsabilidade para 
com a educação de modo geral e para com a formação dos professores em específico.

Quando o poder público promove cursos formativos, nem sempre consegue atingir seus objetivos, porque em muitos casos não há diálogo sobre a prática dos professores, desrespeitando suas necessidades. Em outras circunstâncias, são impostas alterações no sistema de ensino sem que seja oferecido nenhum tipo de curso preparatório e, ainda mais, sem levantar necessidades e opiniões do professorado. SCHÖN (1987b) comenta que as reformas educacionais falham justamente porque os professores não participam de sua elaboração, apenas as põem em prática.

Ao se oferecer cursos de educação continuada que levam em consideração os conhecimentos que o professor possui, resta perguntar se o objetivo é realmente a construção de novos conhecimentos. Se esse é o objetivo, é necessário que o curso esteja integrado na rotina diária de trabalho de forma coletiva, buscando alcançar resultados a longo prazo. Todos esses itens são essenciais para verificar se a forma de implementação está realmente contribuindo para a consecução do objetivo.

O curso precisa estar integrado na rotina e almejar resultados a longo prazo porque essa construção é um caminho pessoal, lento e trabalhoso que deve fazer parte do habitus do professor. Para tanto, deve haver espaço na jornada de trabalho do professor, de maneira que este além de lecionar também estude e discuta.

Outrossim, deve ocorrer de forma coletiva para que o professor não enfrente situações difíceis sentindo-se isolado em sua prática, aprendendo somente por tentativa e erro. Desta forma, as opiniões singulares são submetidas à opinião dos outros, aumentando as chances do professor perceber suas falhas e aprender com os outros. 
Os requisitos citados acima são indicadores da qualidade nos cursos de educação continuada, pois vão além de valores numéricos sobre quantos profissionais participaram do processo e deixam de se caracterizar como um acúmulo de cursos fragmentados. Além desses itens, PIMENTA (2002), acrescenta como categoria de análise, o exame das condições necessárias para a efetivação da proposta, como, por exemplo, o apoio pedagógico e material aos envolvidos e a permanência das equipes escolares na mesma escola.

Isto porque o processo formativo perde continuidade quando o professor tem que mudar de escola por não ser titular da vaga. Com esses critérios de implementação é que se alcança a dimensão necessária, resultando em atendimento de qualidade para além do meramente quantitativo. Deste modo, não é possível acreditar no discurso de oferecimento de educação continuada mediado pela prática reflexiva, com uma política que desqualifica e não investe nas condições materiais da escola, nos salários, na jornada de trabalho e na fixação dos professores na mesma escola.

Segundo PIMENTA (2002), a expressão "professor reflexivo" fez parte dos documentos públicos para formação de professores, mas foi retirado logo em seguida. Se tal conceito fosse levado às últimas consequiências, implicaria transformar significativamente as condições de trabalho dos professores, o que significaria jornada completa e elevação salarial, aspectos estes completamente silenciados nas reformas governamentais de nosso país.

A prática reflexiva coletiva questiona certezas e conhecimentos tácitos, num constante movimento de ida e vinda entre aspectos que vão desde os individuais do professor, de sua relação com os alunos, demais professores e membros da escola, até as políticas públicas para a educação. Possibilita a construção de novos conhecimentos, caminhando em busca do domínio da complexidade envolvida no ato de ensinar, tornando o trabalho mais eficaz e 
contribuindo para uma maior compreensão e transformação dos aspectos estruturais que dificultam o trabalho do professor.

Passaremos agora ao segundo tema dentro da revisão de literatura, que se refere aos diários de aula como estratégia para a prática reflexiva.

\section{$4.2 \quad$ Os diários de aula}

Os diários de aula, segundo ZABALZA (1994), são documentos pessoais valiosos tanto para o pesquisador quanto para o professor. Para o pesquisador, são uma fonte rica em informações. Para o professor, possibilitam não apenas o planejamento da aula, mas principalmente retomar a aula realizada questionando e justificando suas ações.

\subsubsection{Os diários de aula como instr umento de investigação}

De acordo com ZABALZA (1994), nos diários percebe-se não só o decorrer da ação, mas também o que é mais importante, já que se estudam os dilemas ${ }^{5}$ do professor, a evolução do pensamento dos professores ao longo do decurso de tempo percorrido pelos diários.

Este caráter longitudinal e histórico os diferencia de outros documentos pessoais, que ora são pontuais (cartas, documentos sobre momentos específicos), ora constituem reconstruções de períodos vitais a partir de momentos distantes dos fatos narrados (biografia, entrevistas, história de vida).

Os diários vão estabelecendo a seqüência dos fatos a partir da proximidade dos próprios fatos. Por outro lado, apresentam a característica da segmentação do período geral (o conjunto do período narrado) em segmentos

\footnotetext{
${ }^{5}$ Dilemas são construtos que pretendem formular os tipos de tensões que existem no professor em cada situação escolar concreta e na própria sociedade e que dizem respeito à natureza do controle que os professores têm que exercer sobre os alunos.
} 
temporais unitários: a cada dia o professor conta o que passou e, portanto, não volta a escrever até uma próxima vez, introduzindo hiatos temporais na narração.

Isto evita a distorção da perspectiva homogênea de análise dos dados. Quando alguém escreve a sua autobiografia num período narrativo unitário, toda a narração está realizada numa perspectiva bastante homogênea, aquela que corresponde ao momento em que se escreve.

\subsubsection{Os diários como forma de expressão e elaboração do pensamento do professor}

Segundo ZABALZA (1994), os diários são um recurso que implica escrever, expressar-se e refletir.

No processo de escrever, produz-se um feedback autoproporcionado. Como, ao redigir, temos imediatamente o resultado, isso gera um processo cíclico de criação-revisão da informação sobre quem escreve e sobre o que se está escrevendo. Redigir requer uma estruturação deliberada do significado que envolve sintaxe e semântica diferentes da linguagem verbal. Desta maneira, escrever sobre a própria prática leva o professor a aprender mediante sua narração.

Mediante os diários, o professor expressa conhecimentos e recordações da experiência, nos quais intervêm as emoções e a intuição. É o autor quem seleciona os temas e define o sentido do texto.

Além disso, muitas vezes a reconstrução do discurso prático é acompanhada de abordagens reflexivas sobre os porquês e as estruturas de racionalidade e justificação que fundamentam os fatos narrados. Esta reflexão pode se dar sobre o objeto narrado ou sobre si próprio, pois o "eu” que escreve é capaz de ver a si mesmo em perspectiva numa espécie de negociação. 


\subsubsection{Cuidados metodológicos no trabalho com diários}

ZABALZA (1994) levanta a necessidade de cuidados técnicos e de contextualização pragmática em relação ao trabalho com diários.

As garantias técnicas centram-se principalmente na validade dos diários. Validade que se centra, por um lado, no problema da representatividade (não da amostra, mas de significatividade) das unidades textuais recolhidas pelos diários. Por outro lado, na incidência da reatividade no processo de elaboração dos diários.

A representatividade envolve a oposição naturalidade versus artificialidade. Para se amenizar a artificialidade na escrita dos diários, é importante que se estabeleça um vínculo de confiança entre os professores e o formador para que os primeiros escrevam seus diários da forma mais natural possível, sem medo de que seus diários sejam utilizados como instrumento de avaliação ou punição.

Entretanto, mesmo não havendo total naturalidade, não há um verdadeiro comprometimento da validade dos diários. Isto porque o objetivo desta pesquisa não é a fidelidade dos fatos narrados, mas verificar o processo de reflexão das quatro professoras ao longo do curso de educação continuada. Por isso, mesmo que elas fabriquem a realidade que aparece nos diários, não resultará em detrimento significativo da mensagem, porque ao longo das sucessivas narrações irá aparecendo o seu autêntico estilo.

Quanto à reatividade no processo de elaboração dos diários, esta envolve, por exemplo, a dimensão da resistência. Neste caso, é importante saber que os diários são um recurso custoso pelo esforço lingüístico de reconstituir verbalmente episódios densos da vida, bem como pela necessidade de se escrever depois de um dia de trabalho esgotante nas aulas. O esforço é maior ainda 
quando se escreve tanto na fase pré-ativa (planejamento) quanto na fase pósativa do ensino (avaliação).

Esta é uma limitação do trabalho com diários, mas deve-se considerar que logo que os professores se adaptam à sua dinâmica, reconhecem sentido e utilidade nele. Este instrumento, então, costuma ultrapassar os propósitos iniciais do investigador, pois o professor utiliza-o como algo realmente seu e que traz benefícios para seu desenvolvimento profissional.

Além disso, os diários cumprem sua função (e sua realização se torna menos trabalhosa em tempo e esforço) mesmo que sua periodicidade não seja diária. O importante é que não se torne uma atividade esporádica e sem sistematização.

Os cuidados de contextualização pragmática são definidos em três parâmetros:

a) A que tipo de solicitação o professor responde ao escrever os diários;

b) Qual a percepção que o professor tem do papel de si mesmo e do investigador diante da situação de investigação;

c) Como lidar com a relação privacidade-publicidade dos conteúdos dos diários. Para esta questão, ZABALZA (1994) argumenta que os diários não devem ser vistos como um documento privado, mas como um documento pessoal. Além disso, deve-se deixar claro que tipo de dado será tornado público. 


\section{METODOLOGIA}

Esta pesquisa foi submetida ao Comitê de Ética em Pesquisa da Escola de Educação Física e Esporte da USP e aprovado em 26/11/2004. O modelo do termo de consentimento livre e esclarecido assinado pelos sujeitos é apresentado no ANEXO I.

\section{$5.1 \quad$ Sujeitos}

Os sujeitos envolvidos na pesquisa foram quatro professoras (P1, P2, P3 e P4) do primeiro turno de uma EMEI de São Paulo, que participaram do curso de educação continuada em educação física. Todas eram titulares, o que garantiu a permanência destas professoras na mesma escola durante todo o período letivo, possibilitando a continuidade dos projetos iniciados. Estas educadoras cumpriam a Jornada Especial Integral (JEI) que possui uma carga horária de oito horas semanais destinadas a reuniões coletivas entre os professores e o coordenador pedagógico. As quatro professoras lecionavam, em média, há vinte e cinco anos e, além do curso de magistério, três eram formadas em Pedagogia e uma outra em Letras. Portanto, todas possuíam formação superior e traziam uma experiência acumulada ao longo de vinte e cinco anos de carreira. Apesar deste perfil, enfrentaram dificuldades típicas de professores iniciantes, isto porque foi o primeiro contato com a área de conhecimento educação física.

\subsection{0 curso de educação continuada em educação física}

O curso foi ministrado nos anos de 2001, 2002, 2003 e 2004 pelo Professor Doutor Osvaldo Luiz Ferraz, docente titular da Escola de Educação Física e Esporte da Universidade de São Paulo (EEFEUSP), durante a JEI, na 
escola onde as professoras atuavam. Segundo NÒVOA (1992), é preciso conceber a escola como um ambiente educativo, onde trabalhar e formar não sejam atividades distintas. A formação deve ser encarada como um processo permanente, integrado no dia-a-dia dos professores e das escolas.

A pesquisadora esteve presente em todo o período formativo, tendo criado um vínculo com as professoras e demais funcionários da escola. Além disso, já participava do grupo de pesquisa e estudos em educação física escolar da EEFEUSP, de onde surgiu seu interesse em analisar o processo de reflexão sobre a prática pedagógica dessas professoras.

A opção por realizar a pesquisa nesta escola deveu-se ao fato dela situar-se relativamente próxima à EEFEUSP e possuir uma equipe de direção, coordenação e professores compromissados com a educação e dispostos a assumirem parcerias com os profissionais da universidade. Por esse motivo, além do curso de educação continuada, acontece na escola, desde o ano de 1991, um convênio EEFEUSP - Secretaria Municipal de Educação de São Paulo, que proporciona a implementação do projeto de prática de ensino aos alunos do curso de licenciatura em educação física da referida universidade, sob responsabilidade do Professor Doutor Osvaldo Luiz Ferraz.

A decisão pelo curso partiu das próprias professoras que, observando os estagiários de licenciatura em educação física, do projeto citado acima, lecionando para as crianças que estudavam no período intermediário, sentiram a necessidade de conhecer melhor essa área do conhecimento e passar a ministrar aulas de educação física dentro da rotina semanal. Este processo de decisão pela formação em educação física está de acordo com NÒVOA (1992) quando coloca que o fato das necessidades formativas serem identificadas pelos professores, em ligação estreita com o desenvolvimento curricular e a 
organização da escola, favorece a participação dos diversos atores da vida da instituição e a emergência de práticas democráticas.

Este curso compreendeu três fases, a saber: a) Seminários, b) Discussões coletivas semanais e c) Discussões coletivas mensais. Em todas as fases participaram o formador, a pesquisadora, a coordenadora pedagógica da escola e as quatro professoras. Não foram realizados registros escritos das discussões coletivas, embora alguns encontros tenham sido gravados em fitas cassete e a pesquisadora tenha filmado quatro aulas de educação física de cada professora. Mesmo sabendo-se que estes dados poderiam enriquecer as análises, por serem exemplos de outros tipos de representação da prática (aulas filmadas) e da discussão e reflexão coletiva (encontros gravados em fitas cassete), a análise centrada nos diários foi suficiente para o estudo dessa estratégia formativa.

Na primeira fase, houve encontros coletivos mensais para discussão de textos teóricos sobre os objetivos, conteúdos, estratégias e avaliação da educação física infantil.

Considerando-se que todas as crianças, independente de sexo, raça, potencial físico ou mental têm direito a oportunidades que maximizem seu desenvolvimento, e que o movimento tem um papel importante nesse processo, os objetivos da educação física infantil que orientaram a formação continuada foram guiados por FERRAZ (1996):

- Conhecer o corpo globalmente, identificando suas partes, dimensões e movimentos;

- Executar e identificar as diferentes possibilidades de utilização de movimentos;

- Conhecer, respeitar e confiar nas próprias competências motoras e habilidades básicas; 
- Demonstrar conhecimento do ritmo proposto a partir da experimentação e interpretação;

- Participar das atividades de movimento propostas, percebendo e respeitando as normas combinadas e estabelecidas;

- Conhecer, usufruir e apreciar as atividades motoras relacionadas ao tempo livre.

Para auxiliar o processo de aprendizagem das professoras, foi elaborado um quadro de referência onde constam os verbos mais representativos das três dimensões dos conteúdos: conceitual, procedimental e atitudinal (COLL, 1996).

Os conteúdos foram sistematizados em três blocos: conhecimento e controle do corpo, atividades rítmicas e jogo.

As estratégias foram orientadas pelos seguintes estilos de ensino: tarefas e descoberta orientada, de GALLAHUE (1987), além de jogos e circuitos.

Também foi utilizado um quadro de organização dos conteúdos, em que se visualizava a distribuição dos mesmos durante o ano (ANEXO II).

$\mathrm{Na}$ segunda fase do curso, que correspondeu às discussões coletivas semanais, as práticas pedagógicas foram debatidas e orientadas mediante análise dos diários produzidos pelas professoras. A cada reunião uma professora lia seu diário para o grupo, contando o que havia planejado e como havia transcorrido a aula. Neste relato eram apresentadas as dificuldades e facilidades que a professora havia identificado ou que o grupo apontava e, em seguida, eram discutidas novas possibilidades para a aula seguinte. No início, como não havia o hábito de se escrever diários, foi estimulado para que escrevessem livremente o que chamava a atenção durante a aula. Com o tempo, sentiram a necessidade de organizar esses diários de modo a facilitar a escrita, a posterior leitura e a discussão coletiva. Embora nem sempre usassem os termos planejamento e 
avaliação, sabiam que era preciso haver um espaço para o "pretendido" e outro para o "realizado". A partir da orientação do formador e da leitura dos textos teóricos, acrescentaram os itens objetivo, conteúdo e estratégia, além de um espaço extra para comentários. Sendo assim, as próprias professoras criaram uma forma de organização dos diários (ANEXO III).

Estabelecer, mesmo que em grupo, uma forma de organização da redação dos diários pode ter limitado ou modificado a escrita desses diários em relação a uma redação livre. Apesar desta limitação, foram colhidas informações pertinentes que possibilitaram a análise dos dados, não prejudicando o objetivo da pesquisa. Se, por um lado, a organização dos diários pode ter sido um fator limitador, por outro pode ter representado um eixo centralizador diante de tantas descobertas e desafios nessa nova prática pedagógica. Isto porque os diários demonstraram ser uma estratégia rica em informações, tanto para as professoras que ampliaram seu repertório, quanto para a pesquisadora que pôde observar a mudança de enfoque das reflexões ao longo do trabalho. Além disso, possibilitaram o debate no grupo por ser um meio onde as professoras externalizavam a compreensão que tiveram sobre o processo de ação-reflexãoação modificada. Além disso, segundo PERRENOUD (1999), a prática reflexiva precisa ser metódica, inscrita no tempo de trabalho como uma rotina e, ao mesmo tempo, como um estado de alerta permanente. Por isso, tem necessidade de disciplina e de métodos para observar, memorizar, escrever e analisar após compreender.

$\mathrm{Na}$ última fase, as discussões coletivas voltaram a ocorrer mensalmente e as professoras passaram a decidir qual diário ou questão discutir. 


\subsection{Instrumentos}

Foram utilizados os diários das aulas de educação física elaborados pelas professoras e entrevista semi-estruturada.

\subsection{Procedimentos de coleta de dados}

Foram coletados os diários de aula do ano letivo de 2002. O fato de se coletar um ano de diários permite estudar a evolução do pensamento das professoras, de acordo com ZABALZA (1994).

O ano de 2002 foi escolhido por ter sido o mais intenso do curso com as professoras lecionando educação física duas vezes por semana, produzindo diários e participando das discussões semanais. Não só conseguiam escrever os diários, como o faziam para todas as aulas, enriquecendo o posterior debate coletivo. Mediante a escrita dos diários foi possível, às professoras, enxergar em suas aulas o que era importante dentro da especificidade da educação física.

Por outro lado, na primeira fase, ano de 2001, as professoras se familiarizavam com a dinâmica dos diários, não havendo ainda uma prática sistematizada. Encontraram muita dificuldade em escrever e em se expor para o grupo. Demoraram a "se soltar" nos diários e este processo estendeu-se por todo o ano de 2001. Quando a pesquisadora e o formador chegavam na EMEI é que as professoras lembravam de escrever os diários. Com o tempo e a prática, redigir sobre como havia transcorrido a aula já não era tão problemático, porque era uma questão de recordar ações, falas e talvez até alguns sentimentos. Mas para planejar eram necessários conhecimentos em educação física, que as professoras não dominavam. Então, em algumas reuniões, ao invés de se discutir e refletir sobre a prática foram estruturados planejamentos de maneira conjunta, revendo os textos sobre educação física na educação infantil. Também havia, entre 
algumas professoras, o medo de que sua inexperiência em lecionar educação física pudesse causar danos físicos aos alunos. Uma preocupação comum era "o risco da criança machucar gravemente o pescoço ao realizar uma cambalhota", por exemplo. Esta insegurança foi vencida à medida que eram realizadas as práticas pedagógicas e as discussões coletivas.

Já na terceira fase do curso, nos anos de 2003 e de 2004, as professoras estavam envolvidas em outros projetos da escola, dificultando uma regularidade de reuniões e havendo um espaçamento maior entre elas. Participavam de outros projetos porque alegavam possuir, em outras áreas, a mesma deficiência que antes sentiam em relação à educação física. Daí a necessidade de cursos nessas outras áreas. Mas a mudança de prioridade pode indicar também a dificuldade que é, para essas professoras, trabalhar durante muito tempo com os diários de aula. Talvez tenham optado por entrar em outros projetos para não terem que ficar escrevendo e esta pode ser uma limitação do uso dos diários de aula como técnica formativa.

Outrossim, é mais fácil a elas desenvolverem outras áreas onde já possuíam alguma familiaridade, por terem visto o assunto, pelo menos de maneira superficial, durante a formação inicial. Isto indica que os cursos de formação inicial para professores, mesmo que em nível superior, não possuem uma disciplina que trate da educação física adequadamente, embora o Referencial Curricular Nacional para a Educação Infantil (BRASIL, 1998) coloque o movimento como um elemento a ser trabalhado pelos educadores.

As entrevistas individuais com as professoras ocorreram na própria EMEI, ao final do período formativo, correspondendo ao segundo semestre de 2004. O roteiro da entrevista está presente no ANEXO IV. 


\subsection{Procedimentos de análise dos dados}

\subsubsection{E ntrevistas}

Para as entrevistas, foi utilizado o método de Análise de Conteúdo de TRIVIÑOS (1987). Este método pode ser dividido em três fases: pré-análise, descrição analítica e interpretação inferencial. A pré-análise é, simplesmente, a organização do material, permitindo formular os objetivos gerais da pesquisa, as hipóteses amplas da mesma e determinar o corpo da investigação. Na descrição analítica, o material que constitui o corpo do documento é submetido a um estudo aprofundado, orientado, em princípio, pelas hipóteses e referenciais teóricos. Logo em seguida são realizadas a codificação, a classificação e a categorização do material para se formarem os quadros de referência. Neste ponto buscam-se sínteses coincidentes e divergentes de idéias, ou a expressão de concepções "neutras", que não estejam especificamente unidas a alguma teoria. $\mathrm{Na}$ fase de interpretação inferencial, ocorrem a reflexão e a intuição com embasamento nos materiais empíricos, na qual se estabelecem relações que aprofundam as conexões das idéias. $\mathrm{Na}$ interação dos materiais, é preciso que o pesquisador aprofunde sua análise tentando desvendar o conteúdo latente que eles possuem, descobrindo tendências e características dos fenômenos sociais que se analisam.

Portanto, seguindo TRIVIÑOS (1987), a elaboração dos textos extraídos seguiu os seguintes procedimentos:

$1^{a}$ Fase: transcrição, na íntegra, das informações obtidas, com destaques em negrito para os conteúdos manifestos relevantes;

$2^{\mathrm{a}}$ Fase: a partir do texto da primeira fase, especificamente nos seus destaques em negrito, elaborou-se a reconstrução das falas visando a elaboração de um escrito na qual constassem as idéias principais das educadoras; 
$3^{\mathrm{a}}$ Fase: considerando-se as premissas retiradas das fases anteriores, elaboraramse as inferências e a construção dos indicadores para a discussão dos resultados.

\subsubsection{Diários de aula}

Para os diários de aula, foram empregadas as orientações metodológicas de ZABALZA (1994).

Em primeiro lugar, fez-se uma leitura exploratória de todo o texto com o propósito de familiarização com a linha de discurso seguida pelo professor e com o universo de acontecimentos recolhidos nos diários. Esta leitura prévia evitou o risco da tipificação prematura e permitiu, ao mesmo tempo, ter uma imagem completa do discurso, impedindo uma visão fragmentada e atomística das diversas unidades narrativas.

Seguiu-se uma leitura com anotações à margem e seleção das afirmações e dos dados relevantes. Foi o momento em que se tornaram visíveis as redundâncias e os momentos críticos existentes no texto. Essas anotações foram agrupadas em "esquemas de campos", delimitando mais espaços que categorias e não especificando a priori os conteúdos desses campos, permitindo incluir neles os aspectos diferenciais de cada diário. Os "esquemas de campos" apresentam a seguinte forma:

a) Modelos ou padrões idiossincráticos

Possibilitam fazer uma caracterização descritiva da aula com sua dinâmica geral, rotinas, modo de procedimento na realização das tarefas, redundância, estrutura dos papéis e modos de organização, regras, etc. Há diários que insistem em um elemento e outros diários que se prendem a outros elementos. Essa diferenciação é precisamente a "idiossincrasia" do diário e, como conseqüência, do professor que o escreve. É da análise dos padrões 
idiossincráticos do professor que se extrai a perspectiva, isto é, a abordagem geral que parece presidir essa aula, a idéia à volta da qual o professor funciona como profissional.

b) Dilemas com que o professor se debate

Dilemas são um conjunto de aspectos que o professor apresenta como problemático e que constitui um foco constante de preocupação, incerteza ou reflexão. Pode aparecer de forma explícita ou inferir-se de outros comentários sobre o andamento da aula, o progresso dos alunos, etc. Constitui o foco principal de atenção e é em torno de tais elementos que os diários podem desempenhar um papel importante no processo de reflexão compartilhada entre professor e investigador.

c) Tarefas realizadas

As tarefas são as diversas estratégias didáticas que o professor desencadeia em cada uma das situações de aprendizagem pretendidas. Referemse à organização da dinâmica instrutiva da aula, à configuração das atividades, aos conteúdos. São as características de funcionamento da aula, os modos concretos da ação docente. Incluem-se também os aspectos de contextualização, tais como materiais utilizados, sequiência e organização das tarefas, diferença de tarefas de uma área para outra.

Portanto, pela metodologia de análise de ZABALZA (1994), buscou-se identificar as dificuldades enfrentadas pelas professoras ao planejar, implementar e avaliar as aulas dadas bem como os padrões de pensamento de cada professora buscando clarear teorias implícitas, convicções e conhecimentos tácitos. 
Pelo fato de os diários de aula terem sido o instrumento facilitador da prática reflexiva, esta discussão teve como eixo a análise dos diários das quatro professoras, de acordo com a metodologia de ZABALZA (1994), que permite identificar tarefas, padrões e dilemas. Os diários de uma das quatro professoras, já com as anotações de análise, podem ser consultados no ANEXO V. Estes diários exemplificam a análise realizada também nos diários das demais professoras, não anexados para evitar o volume exagerado de dados e comprometimento da compreensão desta pesquisa.

As entrevistas foram utilizadas como suporte para aprofundar os achados dos diários, para rebatê-los ou complementá-los quando necessário. O quadro geral e a formação dos indicadores das entrevistas das quatro professoras estão presentes no ANEXO VI.

Nesta análise, procurou-se verificar se houve, de fato, reflexão. Por isso, a ênfase foi dada aos resultados referentes aos dilemas que, segundo ZABALZA (1994), constituem o foco principal de atenção; e é em torno deles que os diários desempenham um papel importante no processo de reflexão.

Assim sendo, apresentam-se, inicialmente, os resultados referentes aos padrões e às tarefas das professoras. A discussão desses aspectos vem em seguida, possibilitando uma caracterização geral das aulas. 


\subsection{Padrões}

\section{Padrão 1 - A importância das regras nos jogos, na organização da aula e nos comportamentos}

Em relação às regras, houve uma preocupação com sua compreensão e com o respeito a elas, aparecendo, em média, em 30\% dos diários das professoras.

Foram incentivados a construção, a concordância e o cumprimento de regras, além de formas de organização e auto-gestão, conforme planejamento das últimas aulas registradas nos diários.

A professora P1 contou um episódio em que se surpreendeu com um aluno que sempre infringia as regras, mas ao dar-lhe a oportunidade de liderar, escolhendo e conduzindo uma atividade, exigiu que todos a cumprissem.

\section{Padrão 2 - A importância do prazer nas aulas}

O prazer nas aulas apareceu registrado na fala da professora e/ou das crianças, em média, em $30 \%$ dos diários das professoras P1, P2 e P4. Esteve presente em $59 \%$ dos diários de P3.

\section{Padrão 3 - 0 processo de ensino e aprendizagem}

As professoras estimularam a atribuição de significado e dos "porquês" com o uso do jogo simbólico durante a aula e com a conversa de encerramento com os alunos. 


\section{$6.2 \quad$ Tarefas}

\section{T arefa 1 - A organização dos conteúdos}

As quatro professoras contemplaram, durante o ano, os três blocos de conteúdo propostos por FERRAZ (1996):

1) conhecimento e controle do corpo mediante a execução das habilidades básicas de locomoção, manipulação e estabilização com suas variações;

2) diferentes jogos de regra, de exercício e simbólico;

3) atividades rítmicas com rodas cantadas e danças.

O jogo foi um importante elemento das aulas, sendo colocado tanto como um conteúdo da cultura a ser aprendido, quanto como uma estratégia utilizada pelas professoras para a aprendizagem de outros conteúdos.

Cada conteúdo foi trabalhado, de modo geral, em duas aulas. A primeira com o objetivo de fazer os alunos conhecerem e se familiarizem com a estratégia da aula como o jogo, a estafeta, as tarefas ou o circuito, e se familiarizem com o próprio conteúdo. A segunda aula teve como objetivo aumentar a complexidade do conteúdo e/ou melhorar o respeito às regras estabelecidas na estratégia. Exemplos de aumento da complexidade foram a passagem para o trabalho em duplas, a redução do número de bolas disputadas para chutar, o aumento do número de pegadores no pega-pega, etc.

\section{T arefa 2 - A organização das estratégias}

Houve diversificação das estratégias nas aulas sendo utilizados diferentes circuitos, tarefas, estafetas, jogos e variação de materiais como bolas, pneus, aros, colchonetes, caixas, cordas, coletes, banco sueco, cadeiras, apitos, giz, cones, raquetes e rádio com CDs durante o ano.

A estratégia do circuito permitiu a execução de uma variedade de habilidades básicas numa mesma aula. Além disso, o tempo para percorrer cada 
estação era estabelecido pelas crianças individualmente, sendo respeitado o seu ritmo. Por exemplo, em uma aula P2 trabalhou saltos e acrescentou o rolar e o rastejar. Esta estrutura permitiu à professora direcionar sua atenção às crianças com dificuldade na cambalhota. Nas primeiras aulas de circuito, P1 e seus alunos ficaram empolgados, o que os fez comentar que "isso é que é educação física". Provavelmente, por ser uma estratégia de aula diferente dos tradicionais correcotia e pular corda, que já conheciam.

$\mathrm{Na}$ estratégia usando tarefas, foi possível variar as formas de execução das habilidades fundamentais, respeitando as diferenças individuais. Também se pôde realizar, por exemplo, o rolamento, além de três formas diferentes de rebater variando esforço e tempo de acordo com o material. Como as crianças ficavam cinco minutos em cada estação, tiveram a oportunidade de grande quantidade de prática adequada ao seu nível de competência, tanto no rolamento quanto no rebater, respeitando o ritmo de cada um.

No caso da estafeta, utilizando-se cinco colunas, por exemplo, as crianças não tiveram que esperar muito para chegar sua vez. Além disso, a competição entre as equipes melhorou a motivação.

Embora tenha havido diversificação das estratégias, houve predomínio das estafetas. As primeiras estafetas tiveram um fim em si mesmas, uma vez que os alunos não as conheciam e levaram um certo tempo até compreenderem e seguirem suas regras.

Exemplo na avaliação do diário 17, professora P4: “As crianças ao retornarem para a estafeta não ocupavam o mesmo lugar". Portanto, foram necessárias algumas aulas com esse objetivo. Depois desse ponto, de acordo com o diário 19: "Pudemos repetir o percurso várias vezes, chegamos à competição. A organização já está incorporada, eles realizam a tarefa e retornam ao mesmo lugar". 
Com essas repetições, houve intensa prática, contribuindo para a aprendizagem das habilidades propostas. Além disso, a competição entre as equipes melhorou a motivação, já que a possibilidade de aumento da complexidade proporcionou desafios que estimularam os alunos.

A reação dos alunos de P2 às primeiras aulas de estafeta pôde ser observada no depoimento das crianças: "Estas aulas de educação física são ótimas, a gente não pára um minuto. $\mathrm{O}$ chato é quando a gente perde porque tem um que não faz direito". E a professora P2 acrescentou: "A classe tem participado das atividades com mais entusiasmo. Ajudam a montar a estafeta e dão contribuições. As equipes estão mais entrosadas e a cooperação surpreende".

\section{Tarefa 3 - A organização da avaliação}

P2 observou as três dimensões dos conteúdos (atitudinal, procedimental e conceitual) e levou em consideração a opinião das crianças sobre a aula, na medida em que incluía a fala delas nos diários. Em muitos momentos, a professora não avaliava, mas estimulava as crianças a se posicionarem com relação à sua aula, o que era registrado nos diários.

Já as professoras P1 e P4 avaliaram principalmente a dimensão referente aos procedimentos: "houve saltos de diferentes formas" e referente às atitudes dos alunos: "O respeitar as regras ainda está complicado, pois tem aquele que volta e entra no meio da fila".

Nos primeiros diários de $\mathrm{P} 1$ houve um esforço em colocar a fala das crianças avaliando a aula. Entretanto, já no diário 4 escreveu que esqueceu de comentar sobre a aula com os alunos. A partir desse diário, avaliava a aula, mas não colocava a fala das crianças; apenas no último diário voltou a inseri-la.

A professora P3 enfatizou a dimensão atitudinal dos conteúdos, presente na utilização de palavras e expressões como "gostar", "respeitar" e 
"vencer a timidez". Ela menciona as opiniões das crianças sobre sua aula apenas em dois diários. Já P4 não colocou a fala das crianças em nenhuma aula.

\section{Discussão sobre padrões e tar efas}

Os padrões referiram-se à importância das regras nos jogos, na organização da aula e nos comportamentos e também destacavam o prazer nas aulas, além do processo de ensino e aprendizagem.

Ao mesmo tempo em que as professoras se preocupavam com o cumprimento de regras, preocupavam-se também com o prazer nas aulas, demonstrando que uma aula com regras claras não precisa necessariamente ser enfadonha. A professora P3 afirmava, em quase todas as suas aulas, que havia sido divertido, embora tenha enfrentado diversas dificuldades relacionadas à implementação da aula e ao seu estilo de ensino diretivo. Temas que foram tratados mais adiante na seção dos dilemas.

O destaque ao processo de ensino e aprendizagem revelou um comprometimento dessas professoras com a atividade pedagógica, conforme demonstrado por P2 em sua entrevista quando falou sobre a importância da educação física na educação infantil. Segundo ela, sua função era educar considerando e respeitando a característica de movimento que a criança tem durante esse ciclo de escolarização.

Também se considerou o perfil profissional das quatro professoras. Todas tinham magistério e curso de pedagogia, ou especialização em educação infantil. Embora os motivos da escolha da carreira fossem os mais variados e até inusitados, todas demonstraram envolvimento e profissionalismo que transpareceu no esforço dedicado ao curso de educação continuada em educação física. Este quadro era oposto ao de alguns que trabalham com a educação infantil, já que a tomam como um caminho transitório enquanto não alcançam a 
posição desejada, como nos conta ROSEMBERG (1996) ao explicar que a préescola é vista pelos docentes como um "lugar de passagem", significando não ter que enfrentar crianças mais velhas e mais críticas.

As tarefas envolveram a organização dos conteúdos, das estratégias e da avaliação. A análise das tarefas das quatro professoras demonstrou que foram contemplados todos os conteúdos durante o ano, não deixando nenhum à parte. Diferente do que às vezes acontece entre os professores de educação física, que acabam trabalhando apenas os conteúdos com os quais têm maior afinidade e facilidade.

A forte presença do jogo nas aulas reforçou o que diz HUIZINGA (1971): o jogo é uma evasão temporária e voluntária da vida real, capaz de absorver completamente o jogador em uma satisfação que consiste em sua própria realização. Ademais, cria ordem e é ordem, numa perfeição temporária que cativa seus participantes.

Deste modo, o jogo cativou as crianças que dele participaram e contribuiu para o trabalho das professoras que buscavam ensinar questões relacionadas à compreensão, construção e respeito a diversas regras.

Os conteúdos foram trabalhados, em média, em duas aulas para que fossem suficientemente vivenciados pelos alunos e houve diversificação de estratégias e materiais otimizando o aprendizado.

A professora $\mathrm{P} 2$, em particular, valorizou muito a opinião dos alunos na avaliação da aula, demonstrando ter estimulado um ambiente democrático e participativo.

Quando lembramos que estas professoras não lecionavam educação física antes do curso de educação continuada (como tantos outros professores de educação infantil), a análise dos padrões e tarefas indicou uma possível mudança de prática pedagógica dessas educadoras. 
Entretanto, esta análise não permitiu perceber quais inquietações acompanharam as aulas. Afinal, o ensino é uma atividade complexa, em que nem sempre é possível a transferência de tudo o que se escreve no papel para a prática. Conforme foi colocado pelas quatro professoras durante as entrevistas, às vezes não se cumpria tudo o que se planejava devido a vários motivos, como brigas entre as crianças, impossibilidade de uso do espaço (porque ou era usado por outras professoras ou ficava molhado devido a chuvas), além de críticas e sugestões que as próprias crianças faziam (conforme afirmação de P2).

\subsection{Dilemas}

De acordo com ZABALZA (1994), é em torno dos dilemas que os diários podem desempenhar um papel importante no processo de reflexão do professor.

Tais impasses indicaram que as professoras estavam refletindo porque fizeram parte da escrita de vários diários de maneira recorrente, demonstrando uma preocupação constante e uma busca do trabalho mais eficaz mediado por um "laboratório prático" individual e por discussões coletivas.

Surgiram dilemas quanto à relação entre o objetivo estabelecido e o que era avaliado ao final da aula, ao processo de compreensão do que era objetivo, conteúdo e estratégia, à aprendizagem dos termos específicos da educação física, ao estereótipo de gênero e ao tempo de aprendizagem dos alunos. Estes dilemas foram analisados em bloco e, em seguida, foram destacados mais dois deles. O primeiro era concernente à adesão ao curso de educação continuada, que representou o início do processo formativo com suas características de resistência inicial. O segundo referia-se aos alunos durante a aula, que demonstrou a qualidade dos questionamentos feitos pelas professoras quando a formação continuada passou a fazer parte da rotina de trabalho. 
De acordo com PERRENOUD (1999), a prática reflexiva deve ser imaginada como um funcionamento estável, uma prática metódica para domínio da complexidade, inscrita no tempo de trabalho como uma rotina e, ao mesmo tempo, como um estado de alerta permanente.

Além disso, foram identificados dois dilemas específicos com relação a P3. Um deles era referente à implementação da aula, que ia além da dificuldade comum às demais professoras e dificultou sua reflexão sobre atitudes, conceitos e procedimentos dos alunos; o outro, quanto a seu estilo de ensino diretivo.

\section{Dilema 1 - A relação entre o objetivo estabelecido e o que era avaliado ao final da aula}

Houve momentos em que as educadoras avaliavam todos os objetivos e conteúdos planejados; em outros, avaliavam somente alguns e às vezes não avaliavam, ou ainda chegavam a comentar aspectos não relacionados aos objetivos e conteúdos.

Em um diário, em específico, a avaliação de P2 foi oposta à dos alunos. Enquanto a professora comentava que os alunos tiveram dificuldade na habilidade de chutar, mas que ao final da aula estavam melhores; a fala das crianças nesse diário revelou que a dificuldade persistia.

Entretanto, P2 foi a educadora que logo nos primeiros diários descobriu a importância da estimulação e do registro da avaliação realizada pelos alunos. Em sua entrevista, destacou esse aspecto, que colocou em prática durante todo o ano:

... começou a ficar mais fácil e no diário eu escrevia a volta deles, o que eles falavam e como tinha sido a aula. E isso melhorou a atitude deles na escola também. Eles 
lembravam a educação física, vinham pegar o material comigo, iam montar: 'Professora, é assim, assado'; assistiam às aulas da V. e da K. e repetiam. E as interferências deles: 'A gente pode mudar o jogo assim, assado', 'Quantas maneiras a gente pode fazer esse jogo'.

\section{Dilema 2 - 0 processo de compreensão do que era objetivo, conteúdo e estratégia}

Nos primeiros diários, mesmo estando organizados por itens, não havia uma definição clara de objetivo, conteúdo e estratégia. Com o tempo, aumentou a articulação entre estes itens, embora as professoras ainda voltassem a confundi-los esporadicamente.

Algumas trocas de nomes parecem ter ocorrido intencionalmente, como no diário 35 da professora P2 que organizou estafetas, mas chamou de tarefa porque não queria competição entre as filas. A competição levaria à pressa e não conseguiriam conduzir a bola, mas não comentou se, apesar da formação em filas, conseguiu evitar a competição.

O objetivo dos primeiros diários de P3 referia-se a percepção, sensação e interação entre os alunos, nem sempre diretamente relacionadas ao movimento ou à aprendizagem de habilidades motoras fundamentais, por exemplo. Isto tudo demonstra o que todas as professoras reportaram na entrevista, quando disseram que a formação continuada possibilitou cobrir lacunas da formação, ampliar o repertório e, principalmente, adquirir intencionalidade educativa e objetivos a serem alcançados para os conteúdos que já ensinavam. Enquanto na entrevista de P1 a professora afirmou que "antes dava só brincadeirinhas sem a preocupação em alcançar algum objetivo", no diário 9 
da professora P3 a inquietação voltou-se para além das atitudes dos alunos, centrando-se na especificidade da educação física: “... fizemos uma análise do tipo de material utilizado e como ele interferiu no arremesso, na altura, na distância."

Entretanto, esta professora relatou na entrevista que ainda persistia sua dificuldade em identificar o que era objetivo, conteúdo e estratégia; embora tenha dado um exemplo de aplicação:

Por exemplo, correr em obstáculos. Então a criança tem que ter uma direção, tem que saber ocupar o espaço, tem que saber ultrapassar, saltar. E a estratégia é montar um circuito, por exemplo, com arcos, banco sueco e cordas. O objetivo seria, então, eles aprenderem a andar no espaço, e controlarem o tempo. Mas essa é uma dificuldade. Separar o que é objetivo, o que é conteúdo. Outras estratégias são a descoberta orientada, as estafetas e os jogos. Uma dificuldade era o verbo para montar. O que era estratégia, o que era conteúdo, o que era objetivo. 


\section{Dilema 3 - A aprendizagem dos termos específicos da educação física}

Nos primeiros diários, nem sempre usavam termos da educação física e confundiam seus significados, dificultando a explicação da atividade e, possivelmente, refletindo-se nas aulas. A professora P3, no diário 15, por exemplo, usava muitas palavras para dar significado a um termo: "habilidade de utilizar as mãos e os pés como apoio", ao invés de usar o termo engatinhar.

Mais adiante o conhecimento das professoras pareceu aumentar, pois além de utilizarem, nos diários e com os alunos, termos mais precisos e com seus significados específicos como conduzir, passar, finalizar, driblar, rolar, arremessar, estafeta, circuito, etc; avaliavam os alunos de acordo com esse novo conhecimento. Por exemplo, no diário 23 da professora P4:

Usamos as duas mãos para o arremesso e para receber. Foi fácil arremessar, mas difícil receber a bola no começo. Depois eles começaram a se preocupar mais com a força para facilitar para o amigo pegar.

No diário 26 da professora P1, lê-se: "Arremessaram com as duas mãos, mas só depois da intervenção, pois antes pegavam e arremessavam com uma mão". No diário 32 da professora P2: "Começaram a flexionar os joelhos, arremessar com as duas mãos e perceber a velocidade necessária (força) para a bola atravessar o bambolê"”.

A professora $\mathrm{P} 3$, no diário 28, por exemplo, conseguiu descrever aos alunos as principais dicas para se realizar o "quicar bola": "Nessa atividade as crianças observaram a forma de quicar: Primeiro, a mão em concha; segundo, o esforço para a bola saltar (controle); terceiro, o tempo (ritmo do esforço)". 
Já a professora $\mathrm{P} 4$, na avaliação que consta no diário 32, demonstrou conhecimento sobre o aumento da complexidade e sobre os fundamentos do futebol ao comentar: "agora são duas dificuldades: o passe e o chute."

\section{Dilema 4 - E stereótipo de gênero}

Nos primeiros diários das professoras P1 e P2, há anotações sobre a separação entre meninas e meninos durante as aulas.

P2 conseguiu, pelo que consta nos diários seguintes, integrar os alunos, referindo-se às crianças de maneira geral. Voltando a fazer comentários específicos somente em uma aula de ritmo que teve como estratégia a dança (na qual as meninas tinham maior facilidade) e nas aulas da habilidade de chutar (em que os meninos tinham maior facilidade), mas as crianças continuaram participando juntas. Em outro diário sobre a habilidade de chutar, a professora e as crianças identificaram que os meninos têm maior domínio de bola com os pés, mas as próprias meninas avaliaram a aula de forma positiva. Saber que alguns tinham maior domínio de bola com os pés parece não ter atrapalhado a experiência do grupo, contemplando o objetivo da aula.

Já a professora P1, conforme os diários 5 e 6, manteve a separação, mas passou a justificá-la: "Dois grupos, como é mais fácil, meninas de um lado para pular corda e meninos outro grupo." "Novamente em turmas separadas meninas e meninos (para observar e não permitir brigas). (...) Não aconteceram brigas, então acho que numa próxima vez trabalharei a sala toda de uma vez".

Isto demonstra que P1 começou a se esforçar para não separar mais os alunos. A certeza de melhor organização da aula devido à separação homemmulher estava sendo questionada, mas sem chegar à mudança na prática pedagógica. 
Ainda sobre P1, no diário 34 ficou admirada ao ver que os meninos também dançavam as músicas de um CD: "até os meninos foram se soltando."

P1 passou um período sem comentar, em seus diários, sobre a separação. Somente no diário 37 voltou a separar e justificou que o espaço onde fizeram a aula era pequeno para todos, mas poderia ter separado grupos mistos nas duas salas que usou. A separação estava tão introjetada em alguns alunos (talvez não por responsabilidade da professora, mas por influências de fora da escola), que ao serem incumbidos de organizar a aula, como escrito no diário 42, um deles reproduziu a separação dizendo: "Meninas sentem-se lá, meninos do outro lado."

As professoras P3 e P4 não fizeram referência, em nenhum momento, quanto a separar meninos de meninas. Apenas em alguns diários observaram que os meninos tinham facilidade na habilidade de chutar.

\section{Dilema 5 - 0 tempo de aprendizagem dos alunos}

Nos primeiros diários, a professora $\mathrm{P} 2$ parecia esperar que os alunos aprendessem rapidamente, em uma aula, e por isso considerava seu objetivo atingido apenas parcialmente.

Embora P3 não parecesse esperar que os alunos aprendessem rapidamente como $\mathrm{P} 2$, até porque não conseguia implementar algumas de suas aulas; mais adiante começou a perceber que, ao repetir a aula, os alunos se saíam melhor, como no diário 22: "Percebi que repetindo a atividade houve melhor entendimento às regras, onde o respeito às regras foi mais observado."

Já a professora $\mathrm{P} 4$ demonstrou ter consciência de que o tempo de aprendizagem é individual, pois ao avaliar a aula estava consciente de que nem sempre se alcança o objetivo proposto para todos os alunos simultaneamente, 
como no diário 25: "Já com maior controle sobre a bola a maioria das crianças conseguiram realizar a tarefa até o fim."

Com o transcorrer da escrita dos diários, as quatro professoras passaram a utilizar, em geral, duas aulas para cada conteúdo, pois adquiriram uma visão ampliada de planejamento, identificando a necessidade de trabalhar mediante unidades de ensino compostas por mais de uma aula.

Nesses blocos de conteúdo formados mudavam-se as estratégias (possibilitando variedade e quantidade de prática) e aumentava-se a complexidade (aumentando-se a velocidade, trabalhando-se em duplas, etc.).

\section{Discussão sobre os dilemas 1, 2, 3, 4 e 5.}

Nem sempre era fácil para as professoras relacionarem o objetivo estabelecido ao que era avaliado ao final da aula. Um dos motivos pode ser o fato de identificarem quais são as dificuldades das crianças durante a aprendizagem de um conteúdo planejado, mas não darem conta da solução do problema. Então eram feitos comentários sobre outros aspectos que não aqueles problemáticos para os quais as professoras não deram conta, como uma fuga.

Quando as professoras conseguiam, por exemplo, identificar a dificuldade das crianças ao quicarem uma bola já era um avanço, mesmo não solucionando o problema, pois demonstrava que o foco de atenção estava voltado para a aprendizagem de uma habilidade específica da educação física.

Os momentos em que as professoras avaliavam aspectos não relacionados aos objetivos e conteúdos da aula indicaram uma perda do foco que prejudicava a auto-avaliação e o planejamento de aulas futuras, pois deixava de ser feito o ajuste entre o que se pretendia ensinar e a situação real encontrada. Tornou-se, então, essencial a discussão coletiva, quando eram revistos não só o 
planejamento mas, principalmente, a forma de implementação da aula e suas decorrências.

Outro motivo para essa perda de foco pode ocorrer quando a situação real encontrada é tão forte e diferente do que se esperava, que é o que permanece como destaque, desvinculando-se do pretendido inicialmente.

A reflexão na ação perdeu o foco principalmente nos primeiros diários das quatro professoras. Provavelmente porque se deixavam envolver muito mais pelo turbilhão de emoções que faz parte desse tipo de reflexão. Situação compreensível, pois, segundo PÉREZ GÓMES (1992), o profissional encontra-se envolvido na situação problemática que pretende modificar, sendo afetivamente sensível a todos os obstáculos e resistências do momento.

Em diários subseqüentes, houve maior coerência entre o objetivo planejado e o que era avaliado ao final da aula. $\mathrm{O}$ aumento desta coerência demonstrou o entendimento da função de um planejamento, que deixou de ser um momento "burocrático" (termo afirmado pela professora P2 na entrevista) e passou a contribuir realmente para a aprendizagem dos alunos, para a avaliação da aula implementada e para o planejamento da próxima aula.

Os termos específicos da educação física e os objetivos, conteúdos, estratégias e avaliação das aulas foram aprendidos num processo que se observou progredindo com o passar do tempo. Este fato foi ao encontro do que diz ZABALZA (1994) quando afirma que, pelos diários, percebe-se a evolução do pensamento dos professores ao longo do decurso de tempo percorrido. E, de acordo com SCHÖN (1987a), este é um caminho de construção pessoal e, por isso, mais lento e trabalhoso.

A separação entre meninas e meninos presente nos diários de P1 e P2 mostrou que, já durante os anos de educação infantil, estavam presentes 
conceitos e estereótipos sobre gênero; sendo importante refletir-se sobre o tema ao planejar-se aulas de educação física na educação infantil.

A princípio, essas professoras faziam a separação em seus planejamentos de forma tão "natural" que não pensavam no porquê e nem nas conseqüências dessa atitude, permanecendo como currículo oculto. A partir das discussões coletivas dos diários este ponto foi destacado, surgindo a oportunidade de torná-lo consciente.

Em planejamentos subseqüentes, mesclavam-se momentos de justificativa dessa separação, com tentativas de interação, embora P1 tenha apresentado maior dificuldade de mudança na prática pedagógica.

Já as professoras P3 e P4, que não separavam meninos de meninas, não compartilhavam essa decisão com as demais professoras. A questão de gênero, portanto, aparentemente não era um assunto discutido antes da escrita e discussão dos diários.

Diante deste quadro, a educação física deve - dentro da sua especificidade que é o movimento - desconstruir esta "naturalização extremada" dos papéis de gênero. Não só em relação aos conceitos e pré-conceitos das crianças, mas também os das professoras, que podem propiciar a manutenção e o reforço dos estereótipos do comportamento. Segundo SCOTT (1994) essa desconstrução expõe o contexto, antes silenciado, das oposições binárias entre homens e mulheres, mostrando sua real natureza política de relações de poder e deslocando e revertendo sua construção hierárquica.

Os primeiros diários mostraram-se incipientes e confusos. À medida que as professoras participavam das discussões em grupo, escreviam os diários e implementavam as aulas, o que intensificava a articulação entre objetivo, conteúdo, estratégia e avaliação. Assim, a redação "tornava-se mais clara", como afirmaram as professoras P2 e P4 durante as entrevistas. O conhecimento das 
quatro professoras sobre educação física foi aumentando, houve variação das estratégias de ensino, todos os conteúdos foram trabalhados e, além disso, começaram a fazer observações específicas sobre, por exemplo, a técnica de um bom arremesso. Também aprenderam termos específicos da área como estafetas ou conduzir e passar a bola com os pés.

A conquista da intencionalidade educativa com objetivos a serem alcançados e a ampliação do repertório, citados na entrevista das quatro professoras, assim como a integração da educação física às demais linguagens, citada pelas professoras $\mathrm{P} 2$ e P3, foram corroborados pela mudança na escrita dos diários ao longo do ano.

A professora P1 fez uma observação interessante, dizendo que se tivesse acesso aos diários escritos anteriormente, isso facilitaria a escrita dos demais diários. Este pode ser considerado outro aspecto positivo da utilização dos diários de aula como estratégia formativa.

Se, por um lado, o acesso aos diários possibilitaria o uso das informações e conhecimentos acumulados, por outro a ausência dos demais diários evitou que fossem feitas cópias descontextualizadas.

As professoras P1 e P4, durante as entrevistas, destacaram outros benefícios do uso dos diários, afirmando que estes possibilitaram lançar um novo olhar sobre a aula. Além disso, P4 disse que escrevendo os diários percebeu que os alunos conseguiam criar e seguir regras em comum, o que era bom para a organização e senso de responsabilidade em suas vidas.

As professoras P1, P2 e P4 também comentaram nas entrevistas os benefícios das discussões coletivas. Segundo essas professoras, nesses encontros eram lidos os diários de aula sobre o que deu certo e o que não deu certo em cada turma, havendo a troca de idéias e sugestões entre elas. Segundo P1: 
O que era legal nesses encontros de discussão era o envolvimento da sua sala. Descobrir para o que sua sala dá mais (...) E isso ajuda porque às vezes o fulano não tem idéia e acaba: nossa, isso aí pegou bem, então eu posso usar essa estratégia para a minha sala (...) $\mathrm{Na}$ sua sala deu certo isso, então vamos lá, vou usar para a minha. Então uma vai dando idéias para a outra. Isso era ótimo.

Todas destacaram a importância da presença do formador para dar apoio, segurança e retorno sobre a aula planejada, como, por exemplo, em relação à distribuição dos conteúdos e sobre a aula implementada.

Nota-se o espaço de discussão (NÒVOA, 2004; ZEICHNER, 1993) no qual as práticas e as opiniões singulares adquiriram visibilidade e foram submetidas à opinião dos outros. Mediante este espaço, as professoras puderam expor e examinar suas teorias práticas, perceber suas falhas e aprender umas com as outras.

Para NÒVOA (2004), é a partir dessa análise coletiva que se diversifica o repertório pedagógico dos professores e seus instrumentos de intervenção. Essa ampliação do repertório foi uma conquista que surgiu no decorrer do curso.

\section{Dilema 6 - A desão ao curso de educação continuada}

Os diários das professoras $\mathrm{P} 1$ e $\mathrm{P} 3$ não demonstraram resistência ao curso. Tanto nos diários quanto na entrevista de P1 era freqüente o uso da palavra "tranqüilidade". P1 foi a única professora na entrevista que não disse ter 
sido sofrível ou difícil escrever os diários. Segundo ela: “... foi tranqüilo, gostoso, uma descoberta saber que a gente conseguia fazer tudo isso".

Embora nos diários de P3 não estivesse evidente sua resistência, durante a entrevista a professora admitiu que teve muita dificuldade para escrever os diários, principalmente em relação ao planejamento.

$\mathrm{O}$ número de diários escritos por $\mathrm{P} 4$ foi $\mathrm{o}$ menor das quatro professoras. Enquanto P2 escreveu 50 diários durante o ano, P4 escreveu 39 diários para o mesmo período, indicando alguma resistência, confirmada na entrevista quando disse que em alguns momentos não queria ir para as reuniões de discussão e ter que dar satisfação.

P4 foi a única professora que, mesmo participando da formação continuada, alegou que a falta de conhecimento na área da educação física atrapalhou a implementação das aulas. Entretanto, esta professora entrou em contradição, porque também afirmou que aprendeu nos encontros de discussão:

No começo a reunião principalmente norteava a diversificação de atividade. Porque eu não me dava conta do que eu estava trabalhando, às vezes repetida... muito repetitivo. E quando a gente se encontrava lá, nós trocávamos idéias e experiências.

E sobre a redação dos diários disse:

No começo era uma dificuldade. Depois, como assimilamos os conceitos e entramos no ritmo, percebi que é muito importante, porque clareia na cabeça da gente o que faremos com as crianças. 
Nos primeiros diários de $\mathrm{P} 2$, a professora tinha necessidade de escrever que a aula realmente havia sido realizada, pois a primeira palavra que escrevia no item "realizado" é: "sim". Nos diários subseqüentes, P2 ia direto à explicação sobre como a aula transcorreu e fazia a avaliação. A necessidade de afirmar que a aula foi realizada demonstrou a resistência que P2 tinha no início do curso de educação. Esta resistência também apareceu em sua entrevista ao afirmar que no início foi difícil, bem como angustiante e que lutava contra a realização do curso. Isto porque tinha preguiça e considerava o planejamento burocrático, demandando tempo para estudo e planejamento, além da implementação da aula. Ainda tinha a preocupação com o diário para que esse ficasse "bonito", e essa idealização provavelmente dificultava a escrita.

De acordo com PERRENOUD (2001), a relação pedagógica e a gestão da sala de aula envolvem o professor naquilo que ele tem de mais íntimo, naquilo que se refere à sua identidade, à sua maneira de ser no mundo, aos seus valores e atitudes menos negociáveis ou justificáveis. Ao escrever e apresentar ao grupo como foi sua aula, provavelmente as professoras sentiam-se expostas, com medo de enfrentar a opinião dos outros em relação à sua experiência, medo de ver suas certezas questionadas e suas falhas evidenciadas.

A resistência pode ter sido igualmente uma fuga das expectativas que o grupo impõe ao professor. Segundo GOFFMAN (2001), quando o profissional se vê obrigado a aderir aos padrões de valores e de comportamentos da instituição, pode interpretar esta obrigação como uma forma de pressão, reagindo a ela mediante oposição às propostas de trabalho apresentadas.

FOUCAULT (1987) também fala de enquadramento e forte disciplina na escola, onde o corpo é modelado e treinado, devendo obedecer e ser útil. O objetivo desse controle é acabar com sua linguagem, com sua comunicação, formando corpos dóceis e passíveis de dominação. Estes 
enquadramento e padronização das pessoas podem ocorrer na relação do professor com o aluno, mas também podem ocorrer na relação entre os professores durante o curso de educação continuada.

Diante desse quadro, as professoras assumiam uma atitude defensiva. P2, por exemplo, considerava o planejamento burocrático por demandar tempo para estudo e preparação, além da implementação da aula. Mas admitia sentir preguiça. Na verdade, então, não se tratava de burocracia e sim de escrever o planejamento e a avaliação de cada aula, além de participar das discussões em grupo, o que representava um esforço adicional por parte das professoras. E nem todos os professores estão dispostos a esforços adicionais, pelo menos num primeiro momento.

Afinal, os próprios autores que defendem o uso dos diários como meio formativo, como ZABALZA (1994), comentam que escrever diários é um recurso custoso, pois implica a continuidade do esforço narrativo e lingüístico para a reconstrução verbal de episódios densos da vida. Além disso, não é fácil escrevê-los depois de um dia de trabalho esgotante nas aulas. O esforço é maior ainda quando se escreve tanto na fase pré-ativa (planejamento), quanto na fase pós-ativa do ensino (avaliação), como as professoras desta pesquisa.

Nesse sentido, as condições de trabalho proporcionadas pela JEI resultam de uma política pública fundamental que deveria ser estendida a todos os professores.

Esta é uma limitação do trabalho com diários, mas deve-se considerar que logo que as professoras se familiarizam com a dinâmica dos diários, reconhecem neles, de modo geral, sentido e utilidade. Este instrumento então ultrapassa os propósitos iniciais do investigador, pois as professoras o utilizam como algo realmente seu e que traz benefícios para seu desenvolvimento profissional. 
As professoras desta pesquisa encontraram, posteriormente, o sentido e a utilidade dos diários, superando a fase inicial. Isto porque, na entrevista, consideraram que, com o tempo, ficou mais fácil escrevê-los; e que, mediante os diários, preencheram lacunas de sua formação, ampliaram o repertório e passaram a ter intencionalidade educativa, além de objetivos a serem alcançados para os conteúdos que já ensinavam.

As professoras P2 e P4 afirmaram ter aprendido a escrever objetivos, conteúdos e estratégias.

P2 e P3 afirmaram ter integrado a educação física às linguagens oral, escrita, do desenho e do uso da informática, estimulando o interesse por essas linguagens. Essa integração da educação física com as demais linguagens vem ao encontro do que diz NÒVOA (1992), para quem a formação contínua deve capitalizar redes de trabalho já existentes no sistema educativo, investindoas do ponto de vista da sua transformação qualitativa, ao invés de instaurar novos dispositivos de controle e enquadramento.

Além disso, P2 passou a escrever a opinião e a avaliação que os alunos elaboravam, e esta participação das crianças auxiliou no planejamento e implementação das aulas.

Segundo SCHÖN (1987a), nada é mais indicativo do progresso na aquisição de maestria do que um iniciante descobrir o tempo necessário para superar o choque inicial de confusão e mistério passando ao domínio da prática e tempo para ir e voltar repetidas vezes da a ação à reflexão. As professoras parecem ter descoberto este caminho. 


\section{Dilema 7 - Os alunos durante a aula}

As quatro professoras identificaram vários tipos de dificuldades (apresentadas nos QUADROS 1, 2, 3 e 4 abaixo) que as crianças manifestavam durante as aulas. Portanto, este dilema representou um momento ímpar de reflexão durante os encontros de discussão.

Optou-se pela apresentação do dilema 7 sob a forma de quadros para que houvesse melhor visualização dos dados e das anotações realizadas pela pesquisadora. Desta maneira, foi possível se identificar alguns momentos de reflexão na ação e após a ação realizados pelas professoras. 